\title{
A level playing field in anti-doping disputes? The need to scrutinize procedural fairness at first instance hearings
}

\author{
Shaun Star ${ }^{1,2}$ (D) Sarah Kelly ${ }^{3}$
}

Published online: 28 August 2020

(c) T.M.C. Asser Instituut 2020

\begin{abstract}
The WADA Code upholds the virtues of procedural fairness. Minimum procedural guarantees have been strengthened under the 2021 WADA Code and the International Standard for Results Management. However, implementation of these guarantees by National Anti-Doping Organizations (NADOs) and domestic anti-doping panels are critical in ensuring that athletes are afforded procedural fairness. While some countries have enacted reforms in anti-doping dispute resolution infrastructure, other jurisdictions are arguably lagging behind. Since few doping disputes are heard by the Court of Arbitration for Sport (CAS), a strong domestic dispute resolution framework should encourage independence, efficiency and cost-effectiveness, as well as promote consistency and procedural fairness at all levels of hearing. First instance hearings are particularly significant given that CAS is not considered a practical option for many athletes, especially those from developing countries, predominately due to challenges of access to justice and affordability. Irrespective of procedurally unfair decisions at first instance, CAS has the de novo right of review to correct any such irregularities. However, this approach alone is inadequate, especially given that most athletes do not appeal to CAS. CAS, WADA and NADOs all have significant roles to play in ensuring procedural fairness for athletes. WADA and NADOs need to do more to ensure compliance with procedural guarantees at first instance. This paper advances the debate on the importance of procedural fairness and proposes a research agenda to support future reform, arguing that the current anti-doping model needs to reconsider how these important standards are upheld, from first instance until final appeal.
\end{abstract}

Keywords Anti-doping · Procedural fairness · Court of Arbitration for Sport (CAS) · National Anti-Doping Organizations (NADOs) · World Anti-Doping Agency (WADA) · Sports law

\section{Introduction}

In anti-doping disputes, National Anti-Doping Organizations (NADOs) and domestic anti-doping panels play a critical role in ensuring that athletes are afforded procedural fairness and a speedy dispute resolution process after being accused of an anti-doping violation. The World Anti-Doping Code

Shaun Star

sstar@jgu.edu.in

Sarah Kelly

s.kelly@business.uq.edu.au

1 Jindal Global Law School, O.P. Jindal Global University, Sonipat, Haryana, India

2 TC Beirne School of Law, The University of Queensland, St Lucia, QLD, Australia

3 University of Queensland Business School, The University of Queensland, St Lucia, QLD, Australia
(WADA Code) upholds the virtues of fairness. Indeed, CAS jurisprudence has acknowledged that procedural fairness is prescribed in the WADA Code ${ }^{1}$ and that athletes should have a fair and timely hearing in their home country if they test positive for a banned substance. ${ }^{2}$ While Article 8 of the WADA Code mandates that minimum standards of procedural fairness are followed, it permits national systems to adopt different approaches in achieving these standards. Recent years have witnessed positive domestic reforms in

\footnotetext{
${ }^{1}$ See, e.g., B. v. Fédération Internationale de Natation (FINA) (CAS 98/211), award of 7 June 1999; Amar Muralidharan v. Indian National Anti-Doping Agency (NADA), Indian National Dope Testing Laboratory, Ministry of Youth Affairs and Sports (CAS 2014/A/3639), award of 8 April 2015. See also, Dirk de Ridder $v$. International Sailing Federation (ISAF) (CAS 2014/A/3630), award of 8 December 2014; AEK Athens and SK Slavia Prague v. UEFA (CAS 1998/200), Digest II, para 158.

2 USA Shooting and Q. v. Union Internationale de Tir (UIT) (CAS 94/129), award of 23 May 1995, para 59.
} 
anti-doping dispute resolution infrastructure in a number of developed countries. ${ }^{3}$ Such reforms have focused on improving the efficiency, cost-effectiveness and independence of domestic tribunals. Highlighting the success of these domestic reforms, the establishment of Australia's National Sports Tribunal in March 2020 has drawn on the policies and experiences of dispute resolution frameworks in other developed countries such as Canada, New Zealand and the United Kingdom. ${ }^{4}$ Developments and procedural reforms in these developed jurisdictions have been made to promote procedural fairness, expedited results and consistency of decisions. ${ }^{5}$ However, while improved dispute resolution infrastructure exists in some jurisdictions, other jurisdictions - where reforms are much needed—are arguably lagging behind. The amendments to the WADA Code and the enactment of the International Standard of Results Management (ISRM), which come into force on 1 January 2021, introduce more "rigorous standards for fair hearings" 6 and reinforce the importance of minimum standards to ensure athletes are afforded procedural fairness. While it is hoped that the guidelines on strict timeliness which have been introduced by WADA are quickly introduced by NADOs, the substantive updates of the WADA Code do not necessarily reflect sound implementation of procedural fairness norms by NADOs and international federations. As such, monitoring compliance with these procedural fairness norms at first instance hearings is critical.

Even prior to the adoption of the 2021 WADA Code, the jurisdictions that have adopted positive reforms have recognized that while many athletes have the right to appeal to the Court of Arbitration for Sport (CAS), ensuring that athletes have a fair and effective first instance hearing is important. Indeed, relatively very few doping disputes are heard by the CAS as most are disposed of at first instance at domestic tribunals. ${ }^{7}$ In any event, a strong domestic dispute resolution framework will promote consistency and procedural fairness, especially the athlete's right to a fair hearing, at all levels of hearing. Indeed, this has been reinforced by WADA in the ISRM which

"set out the core obligations applicable to the various phases of Results Management from the initial review

\footnotetext{
${ }^{3}$ For instance, in the UK, Sport Resolutions provide independent efficient and cost-effective dispute resolution in sporting disputes, including anti-doping disputes under the National Anti-Doping Panel. In New Zealand, the Sports Tribunal of New Zealand has experienced regular review and reform procedures since its inception. In Canada, the Sport Dispute Resolution Centre of has been responsible for hearing doping, consistently with the Canadian Anti-Doping Program.

4 Wood et al. 2018, p. 12.

5 See, e.g., David 2017, p. 128; See also Wood et al. 2018.

${ }^{6}$ WADA 2019, p 10.

7 David 2017, p. 545.
}

and notification of potential anti-doping violations ... the Hearing Process ... and issuance and notification of the decision... and appeal". ${ }^{8}$

The importance of first instance hearings is particularly significant given that the CAS is perceived as very distant for many athletes, especially those athletes from developing countries. ${ }^{9}$ Not only have some commentators criticized the CAS as being Eurocentric ${ }^{10}$, but the representation of arbitrators typically does not reflect the demographics and unique socio-economic and cultural challenges of athletes from poorer nations. ${ }^{11}$ Most importantly, there are challenges of access to justice and affordability for athletes from developing countries ${ }^{12}$ in addition to potential integrity and independence concerns in their home countries.

WADA strives for harmonization in the anti-doping framework, ${ }^{13}$ ensuring fairness and consistency for all athletes. The WADA Code provides the framework for harmonized anti-doping policy, providing the applicable rules which are followed by athletes and sport organizations. ${ }^{14}$ While the CAS is well positioned to enforce consistent and proportionate decisions that are procedurally fair to athletes, one needs to question whether first instance tribunals are equally well-equipped to promote this harmonization for all athletes? Certainly, while there have been important reforms by WADA in the 2021 Code and corresponding standards, coupled with positive reforms in some countries to reflect the importance of domestic first instance disputes, ${ }^{15}$ such reforms do not appear to have been implemented in developing countries. Indeed, in some of these jurisdictions there is arguably a stronger argument for the need to reform domestic panels since the CAS has regularly heard appeals where athletes have criticized procedural irregularities and delays at first instance, particularly in developing and middleincome countries. ${ }^{16}$

\footnotetext{
8 ISRM, Article 1.

9 See generally, Dasgupta 2019, p. 109.

10 Efverström and Bäckström 2017, p. 8; Dimeo and Møller 2018, p. 7.

11 Sethna 2019. See also, Lindholm 2019, pp. 270-274.

12 Dasgupta 2019, p. 109.

13 WADA Code (2021), The Code: "The purpose of the Code is to advance the anti-doping effort through universal harmonization of core anti-doping elements..." See also, Jacobs and Brandon 2018, p. 206.

${ }^{14}$ Hanstad et al. 2010, p. 418.

15 For instance, New Zealand's Sports Anti-Doping Rules have been amended every year over the past decade. See, New Zealand Gazette, "Sports Anti-Doping Rules". https://gazette.govt.nz/home/NoticeSear ch?act=Sports+Anti-Doping+Rules. Accessed on 14 May 2020.

16 See cases involving Indian athletes, Amar Muralidharan $v$. Indian National Anti-Doping Agency of India, Indian National Dope Testing Laboratory, Ministry of Youth Affairs and Sports (CAS 2014/A/3639), award of 8 April 2015; World Anti-Doping Agency v.
} 
The CAS would of course argue that irrespective of incorrect or procedurally unfair decisions at first instance, it has the de novo right of review to correct any such irregularities. ${ }^{17}$ However, this approach alone is inadequate. It is argued that compliance with procedural fairness norms in first instance hearings and consistent domestic decisions are critical for a robust anti-doping regime. Accordingly, WADA should use its mandate under the WADA Code and the revised International Standard for Code Compliance by Signatories 2021 (ISCCS) to hold NADOs and international federations to account.

This paper will argue that greater attention ought to be paid to the extent that procedural fairness exists at first instance domestic hearings in anti-doping disputes. The paper will first provide an introduction to the anti-doping framework generally and explain why its unique features demand heightened attention to procedural fairness. Following this, the literature and jurisprudence on procedural fairness, generally and in disciplinary disputes, will be discussed. Third, a more detailed analysis of the scope of procedural fairness in anti-doping disputes will be set out, including the importance of the right to a fair hearing, timeliness and access to justice. Following this, the de novo review approach adopted by the CAS will be critically discussed, and its limitations highlighted. Finally, the stark contrast between developed and developing countries will be emphasized, with reference to an Indian case study in order to highlight the potential shortcomings of the current approach. It is argued that the CAS's approach, which focuses on curing any procedural defects on appeal, is insufficient, especially given that the vast majority of athletes do not (and in many cases are unable to) appeal to the CAS. In essence, by allowing NADOs flexibility to adopt their own procedural standards (within broad procedural norms under the WADA Code), WADA has adopted a bottom-up approach, acknowledging the importance of NADOs and domestic panels. While it is hoped that the revisions to the WADA Code, and by reference the implementation of the ISRM, will promote more stringent adherence to procedural fairness, the burden ultimately lies with WADA and NADOs

\footnotetext{
Footnote 16 (continued)

Amit and National Anti-Doping Agency of India (CAS 2014/A/3869), award of 23 November 2015, para 63; World Anti-Doping Agency v. Nirupama Devi Laishram and National Anti-Doping Agency of India (CAS 2012/A/2979), award of 8 November 2013, paras 119-120. See also, Venezuela: International Paralympic Committee (IPC) v. I., Venezuelan National Paralympic Committee (COPAVEN), Venezuelan National Anti-Doping Organization (VNADO) and Sport Federation for Visually Impaired Athletes in Venezuela (FEPOCIVE) (CAS 2012/A/2789), award of 17 December 2012; South Africa: WADA v. Gert Thys, Athletics South Africa and South African Institute for Drug-Free Sport (CAS 2011/A/2435), award of 30 November 2011.

17 Vieweg 2014, p. 389.
}

to ensure that athletes are afforded procedural fairness at all levels of the dispute resolution process. This paper advances the debate on the importance of procedural fairness in the anti-doping dispute resolution process, with a particular focus on the right to a fair hearing, timeliness and access to legal representation. It proposes a research agenda to support future reform, arguing that the current anti-doping model needs to reconsider how these important standards are upheld, from first instance until final appeal.

\section{Anti-doping and dispute resolution}

The WADA Code regulates anti-doping in sport. Most countries and most international sport governing bodies are signatories to the WADA Code, which entered into force in $2003 .{ }^{18}$ A significant step in the adoption of the WADA Code, the International Convention against Doping in Sport, was adopted by the UNESCO General Conference in Paris in October 2005 and came into force in February 2007. ${ }^{19}$ While Member States have adopted the WADA Code through the establishment of NADOs, some Member States have ratified the WADA Code into national laws and regulations in their respective jurisdictions. ${ }^{20}$ In addition, the international sporting governing bodies who are signatories bind athletes to the WADA Code contractually. ${ }^{21}$

As a consequence of this widespread adoption of the WADA Code, athletes are bound by the anti-doping regulations under the Code as well as the corresponding arbitration framework. In practice, "this is a form of compulsory arbitration, the individual only having a choice between accepting the arbitration agreement or refraining from participation in organized sports altogether." 22 This was reaffirmed by the European Court of Human Rights (ECHR) in Mutu and Pechstein v. Switzerland, ${ }^{23}$ where it held that "CAS

\footnotetext{
${ }_{18}$ See, WADA, "Code Signatories", available at http://www.wadaama.org/en/code-signatories.

19 United Nations Convention Against Doping in Sports (2005). It was adopted by the United Nations Educational Scientific and Cultural Organization (UNESCO), was opened for signature on 19 October 2005 and became effective on 1 February 2007, available at, http://www.unesco.org/new/en/social-and-human-sciences/themes/ anti-doping/international-convention-against-doping-in-sport/.

${ }^{20}$ See, WADA, "World Anti-Doping Code", available at http://www. wada-ama.org/en/questions-answers/world-anti-doping-code. See for instance, National Anti-Doping Rules, 2015 (India), Sports Anti-Doping Rules, 2012 (New Zealand).

${ }^{21}$ It should also be noted that under the Olympic Charter, international sporting federations are specifically bound by the WADA Code pursuant to Rules 40, 43 and 45.3, and By-law to Rule 44.6.

${ }^{22}$ Haas 2016, p. 26.

${ }^{23}$ Mutu and Pechstein v. Switzerland, 40575/10 and 67474/10, 2 October 2018.
} 
jurisdiction ... must be regarded as "compulsory" arbitration within the meaning of its case-law". ${ }^{24}$

In anti-doping, disputes are typically resolved in many jurisdictions by domestic panels and appellate bodies in the home country of the athlete. ${ }^{25}$ Consequently, NADOs play a very important role in resolution of anti-doping disputes and most disputes are not appealed beyond the domestic context. It should be noted that in some circumstances, antidoping disputes are heard by panels set up by national and international sporting federations. ${ }^{26}$ While the applicable procedural rules will differ depending on the dispute resolution body that hears the dispute at first instance, there are certain key principles, such as procedural fairness, which are expected to apply at all levels of the dispute resolution process. Whether the first instance hearing takes place via a domestic panel or an international federation, the CAS has appellate jurisdiction for all anti-doping disputes of international athletes under the WADA Code. ${ }^{27}$ Once the CAS has rendered an award, it is final and binding. ${ }^{28}$ In limited circumstances, athletes may appeal decisions of the CAS to the Swiss Federal Tribunal. ${ }^{29}$

Under the WADA Code, athletes typically cannot contest their alleged anti-doping violation in the domestic court infrastructure. ${ }^{30}$ They are bound by the structure established

\footnotetext{
$\overline{24}$ Ibid, para 115.

${ }^{25}$ See for instance WADA Code (2021), Article 7 and International Standard for Results Management (ISRM), Article 1, Anti-Doping Organizations are responsible for the Results Management process, including hearings and proceedings. Under the WADA Code (2021), Article 23, a "Signatory" includes any entity that has accepted and agreed to implement the WADA Code, including: the International Olympic Committee, International Federations, and National AntiDoping Organizations." Depending on the jurisdiction, in most cases, the NADOs establish panels to hear the disputes within their jurisdictions.

${ }^{26}$ This is very often the case in jurisdictions where there is no centralized national tribunal to hear sports and/or anti-doping disputes. Anti-doping disputes of international-level athletes may also be heard by panels established by the international governing body of the relevant sport. In addition, on appeal (particularly before the CAS) very often international federations and NADOs will join as a party to the proceedings.

27 See WADA Code (2021), Article 13.

28 WADA Code (2021), Article 24.1.8 (noting that CAS decisions are final and enforceable subject to a challenge before the Swiss Federal Tribunal).

${ }^{29}$ As the CAS is located in Switzerland it is governed by Swiss Law. Accordingly, pursuant to procedural public policy guarantees are found in Article 190(2) of Switzerland's Federal Code on Private International Law, 1987.

${ }^{30}$ However, recently the European Court of Human Rights has heard disputes from athletes alleging that the anti-doping dispute resolution process is inconsistent with rights afforded to them under the ECHR. See, for example, Mutu and Pechstein v. Switzerland, 40575/10 and 67474/10, 2 October 2018; Platini v. Switzerland, 526/18, 5 March 2020.
}

under the WADA Code ${ }^{31}$ This context is an important starting point in understanding why foundational principles such as procedural fairness are central to anti-doping jurisprudence, which will be discussed further below.

The WADA Code aims to promote clean sport by creating a harmonized regime that ensures a level playing field for all athletes. ${ }^{32}$ Accordingly, the sanctions for using performance enhancing drugs in sport are stringent, so as to punish users and to act as a deterrent. If an athlete tests positive to a banned substance in their system, they face up to a 4-year ban from their sport, for a first-time offence, under the WADA Code. ${ }^{33}$ Under the 2021 WADA Code, athletes may face a ban of up to 6 years for a first-time offence if there are aggravating circumstances that warrant an additional sanction. ${ }^{34}$

Four (or six) years is a significant period of time for any athlete, especially given the relatively short period of time that elite athletes can perform at their peak. ${ }^{35}$ Indeed, 4 years may even mark the end to an athlete's career. ${ }^{36} \mathrm{In}$ addition, an allegation that an athlete has doped is typically coupled with commercial implications (loss of sponsorship and endorsements) and social consequences given the stigma associated with doping in sport amongst fans and other stakeholders. ${ }^{37}$ The WADA Code also sets out stringent rules on athletes, "compulsory arbitration with no right of judicial appeal; strict or what is effectively absolute

\footnotetext{
31 Hard 2010, p. 536; Weston 2009, p. 5.

32 WADA Code (2021), p. 9: "The purposes of the World Anti-Doping Code and the World Anti-Doping Program which supports it are: [t]o protect the Athletes' fundamental right to participate in dopingfree sport and thus promote health, fairness and equality for Athletes worldwide ..."; Ibid: "The purpose of the Code is to advance the antidoping effort through universal harmonization of core anti-doping elements...".

${ }^{33}$ See e.g., WADA Code (2021), Article 10.2.1. Note that this maximum suspension for an anti-doping violation was upgraded from 2 years to 4 years due to WADA amendment in 2009.

34 WADA Code (2021), Article 10.4. It should be noted that while the increase of sanction (from two-years to four-years) under the WADA Code (2015) saw the omission of the concept of "aggravating circumstances", the revised WADA Code (2021) has reintroduced this concept to enable tribunals to "deal with special or exceptional circumstances where an additional period of ineligibility from 0 to 2 years is appropriate" (See WADA 2019).

35 Indeed, the CAS recently handed down a decision banning Chinese Swimmer, Su Yang, for eight years, for a second anti-doping violation. See Court of Arbitration for Sport, "Media Release: Sun Yang is Found Guilty of a Doping Offense and Sanctioned with an 8-Year Period of Ineligibility" (Lausanne, 28 February 2020), available at http://www.tas-cas.org/fileadmin/user_upload/CAS_Media _Release_6148_decision.pdf.

36 See Duval 2019, p. 3, noting that "[a]rbitrators decide on sporting life or death and can by the stroke of a pen end a career through a doping ban".

37 Costa 2013, p. 2; Dimeo and Møller 2018, p. 193.
} 
liability offences; mandatory penalties; an onus on the athlete to dispute positive results; and a standard of proof which is now set at a level of 'comfortable satisfaction' that a doping offence has been committed, and no more." 38 Given the severity of these consequences and the onerous procedural requirements on athletes, ${ }^{39}$ it is essential that athletes accused of using a banned substance are afforded the opportunity to defend themselves through a transparent, fair, independent and impartial process.

While doping violations are regulated by private contract law, ${ }^{40}$ the onerous procedural (and substantive) provisions in the dispute resolution process have led some commentators to argue that such disputes should be considered quasi-criminal in nature and therefore attract stronger procedural protections. ${ }^{41}$ However, despite the many similarities between criminal law and anti-doping proceedings, as well as the significant consequences of anti-doping violations, "athletes charged with a doping infringement are not afforded any of the rights of a criminal trial". ${ }^{42}$ This is consistent with the view that allegations of anti-doping violations under the WADA Code are not "criminal accusations" within the meaning of Article 6 of the ECHR "concerning the right to a fair trial and that therefore the sanctions imposed for these violations are not of a criminal nature". ${ }^{43}$ In any event, other commentators argue that “... doping allegations, regardless of whether they are quasi-criminal in nature, or breach of contract in nature, are accusatory and therefore require a heightened level of fairness, apparent to all parties", ${ }^{44}$ and as such general principles of procedural fairness and "the requirements of a fair trial" need to apply to the process. ${ }^{45}$

In light of the significance of anti-doping violations and the onerous procedures faced by athletes, it is important that the principles of procedural fairness be observed carefully. The following section sets out the importance of procedural

\footnotetext{
${ }_{38}$ Lodge 2008, pp. 246-247.

39 McCutcheon 1999, pp. 65-66.

${ }^{40}$ Lambert 2009, p. 418; Connolly 2006, p. 44.

41 Soek 2006, pp. 272-274.

42 Lodge 2008, p. 247. For instance, typically under criminal law, hearings will follow strict rules of evidence, the burden of proof (whereupon the onus is on the prosecution to prove the case beyond reasonable doubt), rights to cross examine witnesses, the accused has a right to silence etc.

${ }^{43}$ Costa 2019, p. 5. Costa 2013, p. 2. See also Mutu and Pechstein v. Switzerland, 40575/10 and 67474/10, 2 October 2018. See also, Platini v. Switzerland, 526/18, 5 March 2020, para 48 (noting that a disciplinary code prescribed by a sports federation that includes "special measures taken against a member of a relatively small group of individuals, endowed with a special status and subject to specific rules", does not amount to a "criminal offense" against the applicant).

44 Straubel 2005, p. 1223. See also, Lambert 2009, p. 422.

45 Straubel 2005, p. 1263. See also, Polvino 1994, p. 348; Ansley 1995, p. 288.
}

fairness under law, and how it is applied in the context of anti-doping disputes.

\section{What is procedural fairness?}

\subsection{Procedural fairness, an introduction}

Procedures are considered fair to the extent that they ensure the proper application of the minimum standards of fair treatment. ${ }^{46}$ While the scope of procedural fairness in antidoping disputes is further discussed below, simply put, procedural fairness is a "set of minimum standards that sporting federations [and other institutions] must follow in hearing disciplinary matters." ${ }^{47}$ The newly published ISRM, read with Article 8 of the WADA Code, have sought to clarify the minimum procedural standards that CAS, NADOs and international federations need to observe to preserve the procedural rights of all parties involved in anti-doping disputes. The authors argue that these standards are prime facie consistent with the widely accepted principles of procedural fairness and ought to be strictly enforced by all signatories.

Under Article 8.8 of the ISRM, any anti-doping organization responsible for the hearing process ${ }^{48}$ shall respect, at a minimum, the following principles:

- the panel must remain fair, impartial and operationally independent ${ }^{49}$;

- the hearing process shall be accessible and affordable ${ }^{50}$;

- the hearing process shall be conducted within a reasonable time ${ }^{51}$;

- the right to be informed in a fair and timely manner of the asserted anti-doping rule violation(s), the right to be represented by counsel at the athlete's own expense, the right of access to and to present relevant evidence, the right to submit written and oral submissions, the right to call and examine witnesses, and the right to an inter-

\footnotetext{
46 Galligan 1996, p. 7. While the concept of "procedural fairness" is widely recognised across many common law jurisdictions, the similar concept of "due process" is also widely accepted. While these principles have some important nuances under law, depending on the jurisdiction, the authors have used the term "procedural fairness" in this paper to focus on the minimum standards of fair treatment which are acceptable under law.

${ }^{47}$ Foster 2006, p. 3.

48 The hearing process includes the timeframe between the referral of the matter to a hearing panel until the issuance and notification of a decision by the panel. See ISRM, Article 3.6.

49 ISRM, Article 8.8(a).

50 ISRM, Article 8.8(b).

51 ISRM, Article 8.8(c).
} 
preter at the hearing at the Athlete or other Person's own expense ${ }^{52}$; and

- the right for the athlete or other person to request a public hearing. ${ }^{53}$

While the procedural standards set out in the ISRM will be critiqued below, it is important to note that the interpretation of the principles of procedural fairness, and how they should be applied in the context of disciplinary disputes (as well as in other courts and tribunals), has evolved over time. Indeed, it has been argued that the scope of procedural fairness changes with context, ${ }^{54}$ with one judge noting that trying to define fairness is like defining an elephant, “... it is not easy to do, although fairness in practice has an elephantine quality of being easy to recognise" ${ }^{55}$ Despite the difficulties of defining the scope of procedural fairness, Blackshaw (2009) notes that the commonly accepted parameters of "procedural fairness" include: (i) the right to a fair hearing; and (ii) the right to an unbiased decision. ${ }^{56}$ In addition to being the commonly accepted scope of procedural fairness, ${ }^{57}$ as discussed below, these parameters of procedural fairness are also consistent with the interpretation of the athlete's rights under the ISRM and the WADA Code. Accordingly, this accepted scope of procedural fairness will be applied in this paper.

The core principles of procedural fairness are widely recognized and are reflected in international conventions, ${ }^{58}$ incorporated in the rules of international sporting bodies and tribunals, have been applied across all common law jurisdictions,${ }^{59}$ and have long been recognized by scholars ${ }^{60}$ and judges.$^{61}$ The principles of procedural fairness are consistent with the elements of Article 8.8 of the ISRM and with Article 6.1 of the Convention for the Protection of Human

\footnotetext{
52 ISRM, Article 8.8(d).

53 ISRM, Article 8.8(e).

${ }^{54}$ See e.g., Johnson 1985, p. 71. See also, Kaia v Minister for Immigration and Ethnic Affairs (West) (1985) 159 CLR 550, referring to the "chameleon-like" character of procedural fairness. See also, Canterbury Pipe Lines Ltd v Christchurch Drainage [1974] 2 NZLR 34, 357 (Cooke J).

55 Maxwell v Department of Trade [1974] 1 QB 523, 539 (Lawton $\mathrm{LJ})$.

56 Blackshaw 2009.

57 See e.g., Bedford and Weeks 2016. See also, Head 2017, p. 211.

58 See, e.g., Article 6.1, Convention for the Protection of Human Rights and Fundamental Freedoms (European Convention on Human Rights, as amended) (ECHR).

59 See, e.g., Khalon v Attorney General [1996] 1 NZLR 458; Baker v Canada (Minister of Citizenship and Immigration) [1999] 2 SCR 817.

${ }^{60}$ See e.g., Galligan 1996; Bedford and Weeks 2016, p. 147.

61 See, e.g., Cooper $v$ Wandsworth Board of Works (1863) 14 CB NS 180; Ridge v Baldwin [1964] AC 40; Bonaker v Evans (1850) 16 QB 162.
}

Rights and Fundamental Freedoms which provides that "[i] $\mathrm{n}$ the determination of his civil rights and obligations or of any criminal charge against him, everyone is entitled to a fair and public hearing within a reasonable time by an independent and impartial tribunal established by law." 62

While principles of procedural fairness are central to civil and criminal procedure in most jurisdictions, commentators argue that this touchstone of the rule of law must form a critical part of disciplinary proceedings to uphold the integrity, legitimacy, fairness and transparency in such institutions. ${ }^{63}$ To this end, procedural fairness is now considered a central tenet in sports law disputes.

In contrast to the majority of arbitral tribunals, CAS panels rely on previous awards, which strongly influence their reasoning in reaching their decisions. ${ }^{64}$ As a consequence, the CAS has developed what is considered a consistent jurisprudence in the field of sports law over the years. This "judge made sports law" is often referred to as lex sportiva. ${ }^{65}$ The term lex sportiva is commonly used to refer to "a number of (general) principles that CAS has identified, developed, or created and expressed in its jurisprudence." Many of the guiding principles in lex sportiva have been recognized as general leading principles found in legal systems around the world and in international law. ${ }^{67}$ Indeed, one of the core principles, “....perhaps the core principle, to inform the lex sportiva and the larger body of international sports law is fairness." 68

\subsection{Procedural fairness under anti-doping law}

Fair play is a central tenet to sports, both on and off the field. The principle of procedural fairness has been adopted by the CAS as a general guiding principle and is enshrined in the WADA Code for the same reason that it is included in international conventions, state constitutions and common law jurisprudence; namely, to safeguard the fundamental rights

\footnotetext{
${ }^{62}$ Article 6.1, Convention for the Protection of Human Rights and Fundamental Freedoms (European Convention on Human Rights, as amended) (ECHR) (emphasis added).

${ }^{63}$ See, e.g., Blackshaw 2009, p. 1344; Foster 2006, pp. 3-5, 11.

${ }^{64}$ See, e.g., Siekmann 2011, p. 6; Bersagel 2012, p. 189.

65 Casini 2011, p. 1319; Blackshaw 2018, p. 8.

${ }^{66}$ Lindholm 2019, p. 9.

${ }^{67}$ See e.g., AEK Athens and SK Slavia Prague v. UEFA, CAS 1998/200, Digest II, para 156 ("Certainly, general principles of law drawn from a comparative or common denominator reading of various domestic legal systems and, in particular, the prohibition of arbitrary or unreasonable rules and measures can be deemed to be part of such lex ludica."), cited in Lindholm 2019, p. 10.

${ }^{68}$ Nafziger 2012, p. 254; Nafziger 2011, p. 19. See also, Vieweg 2014, p. 393.
} 
of people appearing before courts and tribunals. ${ }^{69} \mathrm{CAS}$ tribunals have recognized the importance of upholding minimum procedural standards, and reinforced the importance of procedural fairness, noting, for example, that " $[t]$ he fight against doping is arduous, and it may require strict rules. But the rule-makers and the rule-appliers must begin by being strict with themselves."70

From an anti-doping perspective, Article 8 of the WADA Code expressly provides an accused athlete at a minimum the right to "a fair hearing within a reasonable time by a fair, impartial and operationally independent hearing panel." ${ }^{, 71} \mathrm{In}$ addition, the ISRM expressly sets out the minimum procedural standards of all anti-doping organizations in the results management process, including strict timelines that must be followed by domestic tribunals. ${ }^{72}$ The CAS has interpreted these provisions (particularly Article 8 ) as consistent with the principle of procedural fairness. ${ }^{73}$ However, the scope of what exactly constitutes a violation of an athlete's right to procedural fairness has until now been unclear ${ }^{74}$ as the CAS typically exercises its de novo right of review when resolving doping disputes and, as such, holds that any earlier procedural irregularities fade into the periphery. ${ }^{75}$ It is hoped that future interpretations by the CAS of Article 8.8 of the

\footnotetext{
69 See, e.g., David 2013, p. 322.

70 USA Shooting and Q. v. Union Internationale de Tir (UIT), CAS 94/129, award of 23 May 1995, para 34.

71 WADA Code (2021), Article 8.1.

${ }^{72}$ See e.g., ISRM, Article 4.2 and Article 8.8(c), discussed below. See also for an example in the Indian context, Article 8.3.7 of the National Anti-Doping Agency Rules (2015), India (which prescribes 20 days for NADA to respond to the athlete's submissions); Article 8.4 of the NADA Rules (which prescribes a 45-day time limit between constitution of the panel and the hearing and a 90 time limit between the constitution of the panel and the written decisions).

73 See e.g., Amar Muralidharan v. Indian National Anti-Doping Agency (NADA), Indian National Dope Testing Laboratory, Ministry of Youth Affairs and Sports (CAS 2014/A/3639), award of 8 April 2015. See also, AEK Athens and SK Slavia Prague v. UEFA, CAS 1998/200, Digest II, para 158.

${ }^{74}$ See e.g., Dirk de Ridder v. International Sailing Federation (ISAF), CAS 2014/A/3630, award of 8 December 2014, paras 109110 , which sets out only the procedural irregularities applicable to that specific case, relying on CAS's de novo right of review to remedy procedural irregularities that exist in that case, leaving the broad procedural fairness provisions open to interpretation to further CAS panels.

75 See e.g., Fazekas v. IOC (CAS 2004/A/714), award of 31 March 2005; B. v. Fédération Internationale de Natation (FINA) (CAS 98/211), award of 7 June 1999; Smith-De Bruin v. FINA, Matthieu Reeb, ed., Digest of CAS Awards II 1998-2000 (The Hague, Kluwer Law International 2002) p. 255-273; Danuite v. International DanceSport Federation (CAS 2006/A/1175), award of 26 June 2007, para 61; USA Shooting and Q. v. Union Internationale de Tir (UIT), CAS 94/129, award of 23 May 1995, para 187; A. v. Fédération Internationale de Luttes Associées (FILA), CAS 2001/A/317, award of 9 July
} 2001.
ISRM will further clarify the scope and practical limitations of procedural fairness in anti-doping disputes.

The WADA Code clearly articulates that athletes should be afforded a fair, timely and impartial hearing if accused of an anti-doping violation, stating that "[r]egardless of which organization conducts Results Management, it shall respect the Results Management principles set forth in this Article, Article 8, Article 13 and the International Standard for Results Management." ${ }^{, 76}$ In addition, the strict minimum guarantees set out in the ISRM are mandatory for all anti-doping organizations involved in any stage of results management, including the hearings process. In practice, if NADOs and international federations do not comply with these minimum standards, they can be held accountable by WADA under the ISCCS.

The general standard required for the way hearings are conducted at first instance and on appeal under Article 8 is mandatory. ${ }^{77}$ Article 8 essentially requires that the dispute resolution process ensures “... a hearing in good time, before an independent impartial tribunal, at which the person facing an allegation has a proper opportunity to present his or her case and after which a reasoned decision will be provided in reasonable time., 78

The ISRM which comes into effect in 2021 sets out the specific procedural requirements which must be observed at all levels of anti-doping hearings. Interestingly, prior to its amendment in 2015, Article 8 of the WADA Code also clearly set out what it intended the content of the minimum procedural standards to include. ${ }^{79}$ While Article 8 was amended in 2015, it essentially set out the same basic principles but in broader terms, thereby bringing the language in line with the "principles [of procedural fairness] generally accepted under international law" ${ }^{80}$ As a consequence, while the WADA Code requires all anti-doping hearings to respect the fundamental principles of procedural fairness, "the Article does not seek to lay down the specific rules by which the fair hearing rights are provided by a tribunal, and the Article (and the notes to it) anticipate that Signatories will meet the standard required in different ways." 81 The language of Article 8 is substantively the same under the 2021 WADA Code, with the exception that the ISRM has

\footnotetext{
$\overline{76}$ WADA Code (2021), Article 7.1.

77 See, e.g., David, 2017, p. 322.

78 Ibid.

79 See, WADA Code (2009), Article 8.1.

${ }^{80}$ See, WADA, "Significant Changes Between the 2009 Code and the 2015 Code, Version 4.0", available at http://www.wada-ama.org/ sites/default/files/wadc-2015-draft-version-4.0-significant-changes-to2009-en.pdf, 8. See also, David 2013, p. 322.

${ }^{81}$ David 2013, p. 234. See also, Soek 2003, p. 8.
} 
been incorporated by reference, which enumerates specific procedural fairness requirements.

A number of scholars have considered the scope of the athlete's right to procedural fairness in anti-doping disputes. ${ }^{82}$ The requirements of procedural fairness were set out by Pound and Clarke (2011), noting that anti-doping panels are required to respect the following principles:

"timeliness; a fair and impartial hearing panel; the right to be represented by counsel (at the person's own expense); the right to be informed in a fair and timely manner of the asserted violation; the right to respond to the asserted violation and resulting consequences; the right to present evidence ...; the right to an interpreter at the hearing ...; and receipt of a timely, written, reasoned decision..."

Pound and Clarke's interpretation is consistent with the language of the 2009 version of the WADA Code. David (2017) has adopted a similar approach in interpreting the scope of procedural fairness, namely:

[t]he components of a fair hearing and their content may vary to an extent with different hearing processes, but the key components would be a hearing in good time, before an independent impartial tribunal, at which the person facing an allegation has a proper opportunity to present his or her case and after which a reasoned decision will be provided in reasonable time. $^{84}$

The content of procedural fairness requirements in these interpretations seems consistent with the revised WADA Code, including the ISRM. Adopting this approach, the following section seeks to elaborate on some of the salient elements of the principle of procedural fairness as they pertain to anti-doping disputes before NADOs and CAS. This is not intended to be an exhaustive discussion of all the elements of procedural fairness in anti-doping. The principles set out in the ISRM will be discussed below, including: (i) fair, impartial and independent hearing (fair hearing requirements include the right to legal representation and the right to request a public hearing); (ii); an accessible and affordable hearing process; and (iii) timeliness.

\footnotetext{
82 See e.g., Straubel 2005; Lambert 2009; Weston 2009.

${ }^{83}$ Pound and Clarke 2011, p. 152. See also, Soek 2003, p. 8; Soek 2006, p. 306.

${ }^{84}$ David 2017, p. 322.
}

\subsection{Elements of procedural fairness under anti-doping law}

\subsubsection{The right to a fair, impartial and independent hearing}

Numerous CAS cases have referred to the importance of the right to a fair hearing ${ }^{85}$ and indeed Article 8 of the WADA Code requires that athletes are afforded "a fair hearing within a reasonable time by a fair, impartial and Operationally Independent hearing panel in compliance with the WADA International Standard for Results Management". The essential principles of a fair trial include "the obligation to offer each party a reasonable opportunity to present its case... under conditions which do not place a party in a situation of substantial disadvantage vis-a-vis the opposing party". ${ }^{86}$ Article 8 of the WADA Code unequivocally imposes minimum standards of procedural fairness and fair hearing requirements for all anti-doping hearing proceedings. ${ }^{87}$

The importance of affording athletes a right to a fair trial is reinforced by the ISRM which provides that "the hearing panel must remain fair, impartial and Operationally Independent at all times". ${ }^{88}$ WADA has explained that the inclusion of this provision was to allay concerns by many that the "impartial hearing panel" requirement under Article 8.1 of the WADA Code was not being followed by all signatories as in some cases, the "same individual is involved in the investigation, the decision to charge an ADRV and the hearing on whether a violation has been committed". 89 As such, Article 8.8(c) of the ISRM now requires that the hearing panel must be operationally independent from the investigation, the decision to charge and prosecute the case.

Not only would the denial of an athlete's right to a fair hearing be a violation of the WADA Code, a failure to afford procedural fairness in the dispute resolution process may provide grounds to set aside the award..$^{90}$ This principle has

\footnotetext{
${ }^{85}$ See, e.g., Vieweg 2014, p. 187, citing, Croatian Golf Federation (CGF) v. European Golf Association. (EGA) (CAS 2010/A/2275), award of 20 June 2011, para 29; FINA v. CBDA and G. (CAS 2007/A/1373), award of 9 May 2008, para 26; Fédération Internationale de Football Association (FIFA) and World Antidoping Agency (WADA) (CAS 2005/C/976\&986), advisory opinion on 21 April 2006, para 126; A. v. Fédération Internationale de Luttes Associées (FILA) (CAS 2001/A/317), award of 9 July 2001, para 6; USA Shooting and Q. v. Union Internationale de Tir (UIT) (CAS 94/129), award of 23 May 1995.

${ }^{86}$ Costa 2019, p. 13.

${ }^{87}$ Lambert 2009, p. 418.

${ }^{88}$ ISRM, Article 8.8(c).

89 WADA 2019, p 10.

${ }^{90}$ Note that procedural public policy guarantees are found in Article 190(2) of Switzerland's Federal Code on Private International Law and are applicable in anti-doping cases at the Court of Arbitration for Sport. In addition, an award may be set aside for public policy reasons under the New York Convention on the Recognition
} 
found its way into most national anti-doping codes, as a measure of guaranteeing athletes their rights to procedural fairness and to ensure minimal procedural delays in doping disputes. It is an oft-quoted principle in CAS decisions. ${ }^{91}$

Athletes have, on a number of occasions alleged that the proceedings of sporting governing bodies and NADOs have not afforded the athlete their right to procedural fairness and a fair trial. ${ }^{92}$ However, the CAS typically shies away from a discussion on whether or not the athlete's procedural rights were in fact infringed as it has a de novo right to re-hear the case in its entirety and remedy and procedural defects that were evident prior to appeal. ${ }^{93}$ This is consistent with ECHR jurisprudence which notes that "a procedural flaw can be remedied only if the decision in issue is subject to review by an independent judicial body that has full jurisdiction and itself offers the guarantees required by Article $6 \S 1$ [of the European Convention of Human Rights]". ${ }^{94}$ Costa (2019) argues that this is indeed the case for the CAS. ${ }^{95}$

However, the ECHR has recently considered decisions from the CAS and Swiss Federal Tribunal (SFT), where the aggrieved parties alleged that their right to a fair trial guaranteed under the European Convention of Human Rights (the Convention) was violated. ${ }^{96}$ In Pechstein, the ECHR concluded that the CAS proceedings were in compliance with fair trial requirements under Article $6 \S 1$ of the Convention, with the exception of the fact that the CAS refused Pechstein her right to a public hearing, which was in violation of the Convention. ${ }^{97}$ This prompted an amendment to

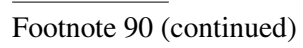

and Enforcement of Foreign Arbitral Awards. See also, David 2013, p. 236.

91 See e.g., WADA v. Amit and National Anti-Doping Agency of India (CAS 2014/A/3869), award of 23 November 2015; Fédération Internationale de Football Association (FIFA) v. Korea Football Association and Kang Soo Il (CAS 2015/A/4215), award of 29 June 2016; WADA v. Nirupama Devi Laishram and National Anti-Doping Agency of India (CAS 2012/A/2979), award of 8 November 2013.

92 See, e.g., N., J., Y., W. v. Fédération Internationale de Natation (FINA) (CAS 98/208), award of 22 December 1998 (the Chinese athletes argued that FINA and their doping panel discriminated against them and did not afford them due process); B. v. International Weightlifting Federation (IWF) (CAS 2004/A/607), award of 6 December 2004, para 41 (the CAS Panel noted that the IWF did not provide the athlete with the opportunity to be heard and to defend himself before the IWF's appropriate body).

93 See discussion below in Sect. 4.

94 ECHR 2019, para 281.

95 Costa 2019, pp. 10, 33.

96 See, most notably, Mutu and Pechstein v. Switzerland, 40575/10 and 67474/10, 2 October 2018; Platini v. Switzerland, 526/18, 5 March 2020.

97 See Mutu and Pechstein v. Switzerland, 40575/10 and 67474/10, 2 October 2018, paras 182-183. the CAS Code ${ }^{98}$ and subsequently the WADA Code. ${ }^{99}$ While Platini also alleged that he was not afforded a fair trial, the ECHR rejected the appeal on the grounds that the appellant did not raise his procedural rights concerns under Article $6 \S 1$ ECHR in his proceedings at the SFT and therefore did not exhaust his domestic remedies. ${ }^{100}$

While the ISRM attempts to dispel concerns of operational independence, particularly with respect to NADOs and sporting federations, questions of impartiality may continue to be raised at all levels of anti-doping disputes. Allegations of bias or impartial panels have been raised previously with respect to first instance hearings ${ }^{101}$ and more recently before the CAS in Pechstein. However, on appeal before the ECHR, the majority held that

"there are insufficient grounds for it to reject the settled case-law of the [SFT] to the effect that the system of the list of arbitrators meets the constitutional requirements of independence and impartiality applicable to arbitral tribunals, and that the CAS, when operating as an appellate body external to international federations, is similar to a judicial authority independent of the parties". 102

This was again reaffirmed by the ECHR in Plantini, where it cited its decision in Pechstein, noting that the independence and impartiality of the CAS was not questioned by the Court. ${ }^{103}$

However, it is important to note that the dissenting opinion of Keller and Serghides in Pechstein leaves the door open for further debate on the issue of impartiality of CAS. The ECHR judges noted in their dissent that "... the structure and composition of the CAS do not meet the requirements of independence and impartiality prescribed in Article $6 \S 1$ of the Convention". ${ }^{104}$ They further noted that:

The structural problems of that arbitral body, together with the questions surrounding the scope of the Court's jurisdiction, should have been subjected to a stricter examination, especially as the CAS constitutes, for a considerable number of professional athletes, the only

\footnotetext{
$\overline{98}$ CAS Code of Sports-related Arbitration, Rule 57.

99 ISRM, Article 8.8(e).

100 Platini v. Switzerland, 526/18, 5 March 2020.

101 For instance, B. v. Fédération Internationale de Natation (FINA) (CAS 98/211), award of 7 June 1999, para 266.

102 Mutu and Pechstein v. Switzerland, 40575/10 and 67474/10, 2 October 2018, para. 157, cited in Duval 2019, p. 11.

103 Platini v. Switzerland, 526/18, 5 March 2020, para 65.

104 Mutu and Pechstein v. Switzerland, 40575/10 and 67474/10, 2 October 2018, Dissenting Opinion of Judges Keller and Serghides, para 2.
} 
appellate body with jurisdiction to review such cases as to both facts and law. ${ }^{105}$

While the impartiality and independence of the CAS has been questioned by appellants before the SFT previously, ${ }^{106}$ the dissenting opinion in the ECHR in Pechstein highlights that it will no doubt be questioned again in the future. Indeed, the question of the independence of the CAS should be given further thought as it goes to the very legitimacy and credibility of the institution.

Although not a doping dispute, the recent decision of Ali Riza v. Turkey ${ }^{107}$ before the ECHR examines the importance of procedural fairness in first-instance disputes in sports. In Ali Riza v. Turkey, the ECHR held that Turkey violated Article $6 \S 1$ of the European Convention of Human Rights after close examination of the structure, organization and operation of the Arbitration Committee of the Turkish Football Federation (TFF). The ECHR held that there were structural deficiencies in the first-instance dispute resolution framework due to the broad powers that the Board of the TFF had over the Arbitration Committee's organization and operation and therefore the applicants had a legitimate reason to doubt independence and impartiality of the members of the Arbitration Committee. ${ }^{108}$ As a consequence, the ECHR ordered the respondent State to reform the system of settlement of football disputes under the TFF, ensuring that such restructuring maintains structural and operational independence from the Board of Directors of the TFF. ${ }^{109}$ This case not only highlights the importance of procedural fairness at first instance, but also illustrates the impact that courts and tribunals (such as CAS and the ECHR) can have when making determinations which encourage domestic reform of first instance procedures if procedural guarantees are not being upheld.

However, since for many athletes the CAS is not perceived as a viable appellate option, first instance panels need to strive for impartiality and operational independence. Accordingly, NADOs play a crucial role in the implementation of the WADA Code, including the need to ensure their independence in operational decisions and activities. In addition, the ISRM requires national appellate bodies to be institutionally independent from NADOs, ${ }^{110}$ ensuring that they are "not in any way be administered by, connected

\footnotetext{
105 Ibid, para 30.

106 See, for example, Swiss Federal Tribunal, Judgment 4A_176/2008 of 23 September 2008; Swiss Federal Tribunal, Judgment 4A_506/2007 of 20 March 2008; Swiss Federal Tribunal, Judgment 4A_234/2010 of 29 October 2010.

107 Ali Riza v. Turkey, 30226/10, 28 January 2020.

108 Ibid, para 222.

109 Ibid, para 242.

110 ISRM, Article 10.2(a).
}

or subject to [the NADO] responsible for results management". ${ }^{111}$ However, in assessing the standards of independence and impartiality should be for first instance panels, Costa (2019) argues that there is a "risk of bias" that exists as a result of the very structure of the organizations. ${ }^{112}$ Costa further notes that even if fair trial requirements are not satisfied at first instance that there is no violation of human rights norms, as long as an appeal can be brought to a Court of "full jurisdiction", including the CAS. ${ }^{113}$ From 2021, significant steps will have to be taken in many jurisdictions to ensure that the operational independence and institutional requirements of the ISRM are fully implemented. This has the potential to improve the legitimacy and reputation of NADOs in some jurisdictions within which there is a perceived (or actual) link between those responsible for investigations, decisions for charging an athlete for an anti-doping violation, and those deciding whether a violation has been committed.

The right for an athlete to request a public hearing before the CAS has long been argued by commentators ${ }^{114}$ and the ECHR in Pechstein confirmed that this right is necessarily to ensure that the athlete is afforded a fair trial. ${ }^{115}$ Following this decision, Rule 57 of the CAS Code was amended to allow athletes to request a public hearing in disciplinary hearings. The ISRM requires that athletes have the right to request a fair hearing at all stages of the results management process, and such a request can only be refused on limited grounds. ${ }^{116}$

Other fair hearing requirements have been expressly enshrined in the ISRM, including the right to be informed in a fair and timely manner of the asserted anti-doping rule violation, the right to be represented by counsel, the right of access to and to present relevant evidence, the right to submit written and oral submissions, the right to call and examine witnesses, and the right to an interpreter at the hearing. ${ }^{117}$

\footnotetext{
111 ISRM, Article 3.1, Definition of "Institutional Independence".

112 Costa 2019, p. 33.

113 Ibid.

114 See, e.g., Cernic 2012, p. 279; Duval 2019.

115 Mutu and Pechstein v. Switzerland, 40575/10 and 67474/10, 2 October 2018, paras 182-183.

116 See comment to Article 8.8(e), the request may be denied by the hearing panel in the interest of morals, public order, national security, where the interests of Minors or the protection of the private life of the parties so require, where publicity would prejudice the interests of justice or where the proceedings are exclusively related to questions of law.

117 ISRM, Article 8(d).
} 
Table 1 Timelimits imposed under domestic anti-doping rules

\begin{tabular}{|c|c|c|c|c|c|}
\hline \multirow[t]{2}{*}{ Country } & \multicolumn{5}{|l|}{ Time limits } \\
\hline & $\begin{array}{l}\text { Notification of ADV/consti- } \\
\text { tution of panel to hearing }\end{array}$ & $\begin{array}{l}\text { Notification of ADV } \\
\text { to written decision }\end{array}$ & $\begin{array}{l}\text { Completion of hearing } \\
\text { to written decision }\end{array}$ & $\begin{array}{l}\text { Completion of hearing to } \\
\text { final written reasons }\end{array}$ & $\begin{array}{l}\text { Notification to } \\
\text { final written } \\
\text { reasons }\end{array}$ \\
\hline Canada & 45 days & NA & 5 days & 20 days & $(65 \text { days })^{\mathrm{a}}$ \\
\hline India (2010) & 14 days & 20 days & NA & NA & 30 days \\
\hline India (2015) & 45 days & NA & NA & NA & 90 days \\
\hline Ethiopia & NA & NA & NA & NA & 120 days \\
\hline Jamaica & \multicolumn{5}{|l|}{ Within a reasonable time } \\
\hline Kenya & \multicolumn{5}{|c|}{ Within a reasonable time, in compliance with WADA's ISRM } \\
\hline New Zealand & $\mathrm{NA}^{\mathrm{b}}$ & NA & NA & NA & 90 days \\
\hline Pakistan & 14 days & 20 days & NA & NA & 30 days \\
\hline South Africa & 90 days & NA & NA & 60 days & $(120 \text { days })^{\mathrm{a}}$ \\
\hline United Kingdom & 40 days & NA & 15 days & NA & $(65 \text { days })^{\mathrm{a}}$ \\
\hline
\end{tabular}

${ }^{a}$ Extrapolated by adding time limits from different stages of the process

${ }^{b}$ Note that under the Sports Tribunal of New Zealand, Rules of the Sports Tribunal of New Zealand 2012, r 37, "[t]he Tribunal will normally convene a pre-hearing conference which will usually be held within five working days of the respondent filing the notice of defence/participation" (emphasis added)

\subsubsection{Timeliness}

While Article 8 of the WADA Code has for many years required disputes to be resolved in a "reasonable time", the amendments which come into force in 2021 reinforce the importance of timeliness. Article 8.8(c) of the ISRM notes that the "hearing process shall be conducted within a reasonable time", specifying further in a comment that "[s]ave in complex matters, this timeframe should not exceed two (2) months." Under previous editions of the WADA Code, no express time limit was included with respect to the hearing process.

Importantly, the ISRM has identified "timeliness" as a guiding principle for all stages of results management, including the hearing process. Article 4.2 of the ISRM requires:

In the interest of fair and effective sport justice, antidoping rule violations should be prosecuted in a timely manner. Irrespective of the type of anti-doping rule violation involved ... Anti-Doping Organizations should be able to conclude Results Management (including the Hearing Process at first instance) within six (6) months from the notification [of the anti-doping violation to the athlete].

While it is mandatory for all anti-doping disputes to be resolved in a timely manner, the 6 month time limit is a guideline. ${ }^{118}$ However, the ISRM notes that NADOs may

$\overline{118 \text { See ISRM }}$, Comment to Article 4.2. face consequences in case of severe or repeated failures to comply with this requirement. ${ }^{119}$ This is consistent with the International Standard for Code Compliance by Signatories (ISCCS) which provides WADA with a mechanism to hold NADOs to account for non-compliance with the WADA Code and ISRM. The authors argue that the specific time limits which are enforceable under the 2021 WADA Code provide a mechanism to hold NADOs accountable to this important procedural fairness requirement. While the previous versions of the WADA Code did not prescribe specific time limits, a number of NADOs prescribe specific time limits under their applicable rules. For instance, under India's NADA Rules, the anti-doping disciplinary panel shall "commence ... within 45 days of the constitution of the ... panel" and "issue a written decision with its reasoning within 90 days of the constitution of the ... panel". ${ }^{120}$ In any event, hearings "should be completed expeditiously and in all cases within three (3) months of the completion of the results management process described in Article 7..."121

While India's NADA Rules were revised to reflect changes in the WADA Code, it is interesting to note that under previous versions of the NADA Rules, anti-doping panels were required to meet strict timelines, such as (i) "commence the hearing within fourteen (14) days of the notification date" ${ }^{122}$; (ii) "issue a written decision within

\footnotetext{
$\overline{119}$ See ISRM, Comment to Article 4.2.

120 National Anti-Doping Rules, 2015 (India), Rule 8.4.

121 National Anti-Doping Rules, 2015 (India), Rule 8.3.9.

122 National Anti-Doping Rules, 2010 (India), Rule 8.3.8.1.
} 
twenty (20) days of the notification date" 123 ; and (iii) "issue written reasons for the decision within thirty (30) days of the notification date." 124 Whether these timelines were in fact met in practice, is a question that has not yet been answered as no empirical research exists that assesses compliance. Nonetheless, the fact that mandatory timelines existed under the NADA Rules, 2010, provided athletes with a mechanism to hold the authorities to account and to argue for their disputes to be resolved expeditiously.

There does not appear to be any consistency in the time limits imposed by NADOs around the world and it will be interesting to observe how quickly the applicable NADO rules are amended to ensure consistency with the 2021 WADA Code. From an analysis of the current applicable rules, it is evident that the length of times that athletes may be expected to wait varies considerably from jurisdiction to jurisdiction (and this assumes that the first instance panels are complying with the time limits). Table 1 illustrates how a number of jurisdictions have prescribed time limits applicable to ensure that disputes are resolved in a "reasonable time". ${ }^{125}$ "Appendix A" sets out the relevant provisions of the countries' applicable rules in further detail.

Prior to the 2021 WADA Code, commentators argued that WADA should impose "mandatory time-frames which can only be departed from in exceptional circumstances", ${ }^{126}$ to ensure that there is no unnecessary and unreasonable delay. Now that the ISRM imposes such time limits, NADOs will be required to update their applicable rules. It is evident from the table above that most NADOs already require the hearing process to take place within prescribed 2 month period, set out in the ISRM. Whether these timelines are complied with in practice is another question altogether.

With the consent of WADA and the relevant NADO, an athlete may request a single hearing before CAS, rather than exhaust the hearing process at a domestic level. ${ }^{127}$ In such cases, the CAS essentially acts as a court of first instance. Of course, this mechanism may not be practically possible for all athletes given the perceived accessibility and affordability issues associated with CAS disputes. In addition to single hearings, the WADA Code permits WADA to appeal directly to the CAS if a NADO fails to give a decision within a reasonable deadline set by WADA. ${ }^{128}$ While one would

\footnotetext{
$\overline{123}$ National Anti-Doping Rules, 2010 (India), Rule 8.3.8.2.

124 National Anti-Doping Rules, 2010 (India), Rule 8.3.8.3.

125 These jurisdictions were selected as their national doping rules were publicly available in English

126 David 2013, p. 384

127 WADA Code (2021), Article 8.5.

128 WADA Code (2021), Article 13.3. For an application of this Article, see World Anti-Doping Agency (WADA) v. Gert Thys, Athletics South Africa (ASA) and South African Institute for Drug-Free Sport (SAIDS) (CAS 2011/A/2435), awarded on 30 November 2011.
}

assume that the deadlines established under the ISRM may be a guideline for what constitutes a "reasonable deadline", WADA has noted that given the different circumstances of each case, it is not possible to establish a fixed time period for a NADO to render a decision before which WADA may intervene by appealing directly to CAS. ${ }^{129}$

The WADA Code also acknowledges that there may be a retrospective commencement of sanction for delay in the dispute resolution process not caused by the athlete. ${ }^{130}$ In effect, this provision attempts to indoctrinate the principle of procedural fairness which ought to be afforded to athletes. As a result, in cases where there have been substantial procedural delays not attributable to the athlete in doping disputes, their period of ineligibility may, at the discretion of the panel, commence at a date they deem most appropriate. ${ }^{131}$

CAS arbitrators have acknowledged that " $[\mathrm{t}]$ he failure to maintain a low cost and rapid procedure could become the undoing of many positive developments associated with CAS..."132 Thus, there is a consensus that anti-doping disputes need to be resolved quickly and effectively, yet despite this, there are often examples of significant delays in antidoping disputes, particularly at the NADO level.

The impact of undue delay is particularly clear in cases where an athlete's sanction is reduced on appeal, yet in the meantime an athlete has served a suspension which exceeds the revised reduced sanction. For instance, Sherone Simpson and Asafa Powell were both sanctioned by the Jamaica Anti-Doping Commission (JADCO) and received a reduced sanction on appeal to CAS. ${ }^{133}$ While both athletes tested positive to a banned substance in July 2013, JADCO only convened a hearing in January 2014 and reached a decision in April 2014. Simpson and Powell appealed their 18-month ban (from the date of sample) to the CAS. Acknowledging the likelihood of success of their claim and the irreparable harm that would be caused by not staying the initial suspension, the CAS ordered provisional relief to the athletes, effectively lifting their ban until a final decision of the CAS could be reached. ${ }^{134}$ Ultimately, the CAS reduced Simpson and Powell's sanctions from 18 to 6 months. However, the

\footnotetext{
129 WADA Code (2021), Comment to Article 13.3.

130 WADA Code (2021), Article 10.13.1. See, e.g., also, National Anti-Doping Rules, 2015 (India), Article 10.11.1.

131 Under the WADA Code (2021), the burden is on the athlete to prove that the delay was not attributable to them.

132 French $v$ Australian Sports Commission and Cycling Australia (CAS 2004/A/651), awarded on 6 September 2005, para 14-15, cited in Hayes 2007, p. 4.

133 Simpson v. Jamaica Anti-Doping Commission, CAS 2014/A/3572 (2015); Powell v. Jamaica Anti-Doping Commission, CAS 2014/A/3571 (2015).

134 See, Simpson v. Jamaica Anti-Doping Commission, CAS 2014/A/3572 (2015), para 3.16.
} 
athletes had already served a 12-month ban when the CAS made its decision. Arguing that the athletes were irreparably harmed, counsel for the athletes, Paul Greene, noted that "[t]here was no way for [the athletes] to go back in time and get back the 6 months and millions of dollars in earnings they had lost. The exceedingly harsh language used by the CAS against the JADCO provided at least some solace for them". 135

Greene (2017) further noted that the decision of the panel stated that:

The Panel is persuaded that, considering the facts and circumstances, it is firmly of the view that the process in Jamaica has been conducted by [the] JADCO in egregious violation of multiple requirements of the WADA Code, and the result of that conduct has been to effectively punish an athlete well beyond what was reasonable, appropriate, or necessary under the circumstances. ${ }^{136}$

JADCO's undue delay at first instance was criticized by the CAS but it is not the only example where the CAS has criticized undue delay in domestic anti-doping disputes. ${ }^{137}$ Similarly, there are a number of cases where domestic appellate bodies have overturned or reduced first instance panel decisions where athletes have already served more than the required period of ineligibility. ${ }^{138}$ This highlights the importance of procedural and substantive fairness at first instance.

WADA's Results Management, Hearings and Decisions Guidelines, which will now in effect be replaced by the ISRM, note that "[a]ny process delay is potentially harmful to the sport and the fight against doping". ${ }^{139}$ A notable omission to the potential harmful impacts of undue delay is the consequences for the athlete. This is clear in the examples above where the athletes have suffered an irreparable harm-a substantive unfairness. On a practical level, delay

\footnotetext{
135 Greene (2017), p. 344. See also, Powell v. Jamaica Anti-Doping Commission, CAS 2014/A/3571 (2015), para. 45.

136 Ibid.

137 See discussion below regarding Amar Muralidharan v. Indian National Anti-Doping Agency (NADA), Indian National Dope Testing Laboratory, Ministry of Youth Affairs and Sports (CAS 2014/A/3639), award of 8 April 2015.

138 For instance, see Indian cases where suspensions were reduced or set aside after a period of ineligibility had already been served: (i) Bhupinder Singh v. NADA, Case 7/ADAP/2012, on 9 December 2012 (suspension lifted after 1 year and 4 month ban had already been served by the athlete); (ii) Harpreet Singh v. NADA, Case 7/ ADAP/2014, on 6 August 2014 (the 6 month suspension was set aside on appeal after the athlete had served 1 month suspension); (iii) Monisha S. v. NADA, Case 27/ADDP/01/2014, on 16 February 2015 (sanction overturned on appeal at ADAP on 28 January 2016 after an 11.5 month suspension).

139 WADA, Results Management, Hearings and Decisions Guidelines
} (2014), Article 5.2.1. may also lead to difficulties in bringing certain evidence before a panel. ${ }^{140}$

Resolving a dispute in a reasonable time is an important part of procedural fairness. Indeed, some scholars argue that resolving a dispute without undue delay is at the heart of civil justice systems. For instance, Zuckerman argues that justice has three dimensions: time, cost and accuracy of the decision. ${ }^{141}$ That is to say, achieving substantively the right outcome is not always enough to ensure justice between the parties. Justice also requires that the correct outcome is reached in a reasonable time and in a cost-effective manner. This perception is shared by a number of jurists in common law courts ${ }^{142}$ and scholars of international arbitration. ${ }^{143}$ While these commentaries reflect the need for speedy resolutions of civil disputes, the argument for expediency in disciplinary matters is arguably even stronger given what is at stake for the accused.

The importance of fast and effective justice is all the more important in the context of an athlete for whom a few months is a long time relative to the career of an athlete. ${ }^{144}$ While suspended (or provisionally suspended), an athlete is not permitted to participate in major sporting competitions and in many respects is not permitted to participate in formal training under the governing body. As such, “... the non-participation in major sports competitions can cause irreparable harm in view of the brief career of most athletes, especially if it is subsequently found to be unjustified." ${ }^{145}$ In addition, athletes often face intense media scrutiny throughout their suspensions, typically without the support of their sporting federation. As such, compliance with timeliness provisions is critical for upholding procedural fairness rights of athletes.

\subsubsection{Access to justice}

Article 8.8(d) of the ISRM requires that the hearing process must be "accessible and affordable". The inclusion of this provision from 2021 is significant because an athlete's

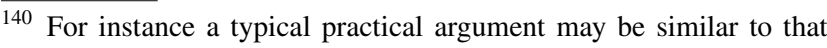
articulated in Christian Craig v. FIM, Decision of the FIM International Disciplinary Court, 29 July 2019, para 41 (arguing that "[d] ue to the delay in notification of the Adverse Analytical Finding, [the athlete] was unable to source the same ingredients and identify the source of the prohibited substance").

141 Zuckerman 1999, p. 3; Zuckerman 2009, p. 90; Zuckerman 2006, pp. 65-68.

142 See, e.g., Spigelman 2000; Bingham 2006.

143 Fortese and Hemmi 2015, p. 116.

144 Cernic 2014, p. 19.

145 Mavromati 2018, p. 31, citing, K. v. FEI (CAS 2008/A/1569), award of 2 February 2009, Elkin Soto Jaramillo and FSV Mainz 05 v. CD Once Caldas and FIFA (CAS 2008/A/1453), award of 10 July 2008, para 7.1.
} 
access to justice is an important issue given what is at stake for their career and livelihood. Commentators argue that since athletes are required to submit to mandatory testing, with significant potential liability, and to a process of mandatory arbitration, they "should be provided meaningful access to competent legal representation when their athletic careers are in jeopardy." ${ }^{146}$ In fact, accused athletes often find that the system is so challenging and costly that they may be prompted to abandon any effort at defense ${ }^{147}$ and when they do decide to argue their case, athletes "lack an institutional support system that can advise them of their legal rights and provide effective representation." 148

Under the WADA Code, athletes have the right to be represented by counsel at their own expense. ${ }^{149}$ Pursuant to this provision, "[a]thletes often need to pay for their own legal representation, which can be (unpredictably) expensive." 150 For many athletes, engaging a competent legal counsel with anti-doping experience is unrealistic, ${ }^{151}$ particularly in developing and middle-income countries. Indeed, in a number of developed countries panels of pro bono counsel have been established to ensure that athletes can be represented by lawyers during anti-doping disputes. ${ }^{152}$ While it is likely that some lawyers represent athletes pro bono in developing countries, this is not managed in any coordinated fashion by the NADOs or any independent body. The ISRM recommends that "the Results Management Authority and/ or the relevant hearing panel should consider establishing a legal aid mechanism in order to ensure such access". ${ }^{153}$ No such legal aid mechanism exists in most jurisdictions. As such, while some highly paid athletes can afford to pay for experienced (and expensive) legal counsel, most cannot. Indeed, many athletes around the world live under the poverty line-including many athletes in developed countries. ${ }^{154}$ Thus, the cost of quality counsel may create a further imbalance against athletes who would benefit from

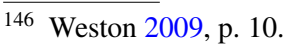

147 Hiltzik 2006. See also, Dimeo and Møller 2018, p. 83.

148 Weston 2009, p. 8.

149 WADA Code (2021), Article 13.2.2; ISRM, Article 8.8(d).

150 Dimeo and Møller 2018, p. 193.

151 Weston 2009, p. 49

152 For instance, Sports Resolutions UK, http://www.sportresolution s.co.uk/services/pro-bono-legal-advice; Sports Tribunal of New Zealand, http://www.sportstribunal.org.nz/rules-and-procedures/legal/.

153 ISRM, Comment to Article 8.8(b).

154 See, for example, Australian Sports Commission 2008, p. 55, noting that: "Apart from those in professional sports, the large majority of athletes in Olympic, Paralympic and Commonwealth Games sports do not derive a living from sport. In fact, many live below the poverty line, making great financial, personal and future career sacrifices to represent their country".
}

quality and experienced counsel to help them navigate the complex anti-doping dispute resolution system.

The right to representation at the anti-doping hearings is so important that India's NADA has listed it twice (probably erroneously) under the NADA Rules (Rule 8.3.5 and Rule 8.3.12). Given the importance placed on access to justice under the NADA Rules, one would hope that most athletes are represented by legal counsel during panel hearings. However, no empirical research exists to ascertain whether this is the case. Given the access to justice obstacles discussed above, one might assume that this is indeed not the case in practice.

Access to justice issues manifest themselves in other ways as well. For instance, some argue that "... the law relating to sport must be publicly accessible." 155 Duval (2019) argues that even though the CAS is publishing a substantial share of its awards, "its publication practice remains erratic and piecemeal", ${ }^{156}$ further arguing that the "systematic publication of CAS appeal awards ... [is] a vital move to ensure the legitimacy of the CAS as the supreme court of world sport". ${ }^{157}$ To an even greater extent than the CAS, most NADOs still do not publish the awards of athletes who have committed anti-doping violations. Publication of awards would allow stakeholders to make more informed decisions of their legal rights and obligations.

In addition, there is arguably a lack of access to expertise (other than legal counsel) for athletes. While athletes have a "right to call and examine witnesses", ${ }^{158}$ scientists and laboratory directors who are accredited by WADA are not permitted to counsel or assist an athlete. In addition to issues of cost, this presents significant practical constraints for athletes in calling qualified, experienced and credible expert witnesses. Accordingly, "[t]he ability of an athlete to assess and meet his burden of establishing laboratory errors in analytical positive cases is thus nearly insurmountable, particularly without the ability to enlist the assistance of qualified experts." 159

Obstacles of access to justice are even more pertinent in developing and middle-income countries where there is limited access to local expertise who can advise athletes on the very technical issues of anti-doping disputes. ${ }^{160}$ For instance, in India, Dasgupta (2019) notes:

The situation prevailing in India best exemplifies the developing country ... dilemmas. Caught within this

\footnotetext{
155 Hayes 2007, p. 6.

156 Duval 2019, p. 17.

157 Ibid, p. 20.

158 ISRM, Article 8.8(d).

159 Weston 2009, p. 37.

160 See, e.g., Dasgupta 2019, p. 109.
} 
web of disinformation and no information, developing country athletes are left to fend for themselves. This lack of support extends right from the day the first pill is inadvertently consumed to the day the arguments are closed before the Court of Arbitration of Sport. ${ }^{161}$

The United Nations Human Rights Council recently argued that sport organizations “... should act to ensure effective forms of redress that conform with international human rights law and that are equally accessible to all athletes regardless of resources and geographic location." 162 However, as argued above, in many developing countries in particular, low incomes, literacy and language challenges compound the issue of access to justice and access to expertise. Whether and how these procedural challenges and inequalities at a domestic level can be addressed is an important issue. While the anti-doping framework places a heavy reliance on NADOs to uphold minimum procedural guarantees, currently the main check and balance of the system is the athlete's right of appeal to CAS. While the CAS has the power to remedy procedural irregularities, placing too great an emphasis on the ability to fix procedural flaws on appeal risks entrenching systemic problems at first instance even more. The following section critiques the current approach of CAS, noting the shortcomings of relying only on the de novo review mechanism to fix procedural problems in the anti-doping regime.

\section{Curing procedural defects on appeal}

As discussed above, the applicable law requires disciplinary bodies at all levels to respect the procedural rights of athletes. Despite these policies and consistent jurisprudence upholding the virtues of procedural fairness, there are numerous instances where athletes have alleged that their right to a fair hearing has not been fulfilled. In such instances, the CAS has interpreted its procedural rules to allow a full review of the merits of the case, thereby vitiating any procedural irregularities that may have taken place in earlier tribunals. ${ }^{163}$ That is, the CAS will accept all evidence (including new evidence) to allow the athlete to cure any procedural irregularity that may have occurred earlier. This approach is consistent with the interpretation of the scope of judicial review in many common law jurisdictions. ${ }^{164}$

\footnotetext{
161 Ibid.

162 United Nations Human Rights Council 2020, para 62.

163 David 2013, pp. 235-236; Straubel 2005, p. 1217.

164 Calvin v. Carr (1980) AC 574. De Smith 1980, p. 242, cited in Sreeshyla Industries Employees' Union vs State Bank of India and Anr., 198557 CompCas 639 Kar, 1984 (2) KarLJ 105.
}

Pursuant to the WADA Code ${ }^{165}$ and the CAS Code, ${ }^{166}$ the CAS panel may undertake a de novo hearing to review the athlete's case, providing "a completely fresh hearing of the dispute between the parties". ${ }^{167}$ As such, if an athlete makes any allegation of the denial of their right to procedural fairness or any other procedural defect which may have occurred at first instance, it will be cured by the CAS and "the [CAS] is therefore not required to consider any such allegations". ${ }^{168}$ The CAS has regularly held that any alleged violations of the athlete's procedural rights simply "fade away into the periphery"169 and the CAS can remedy such defects on appeal. ${ }^{170}$

However, CAS panels have held that in exceptional circumstances certain departures from an athlete's rights "will be treated as so serious that ... they will be considered to undermine the fairness of the testing and adjudication process to such an extent that it is impossible for the [arbitrator] to be comfortably satisfied that a doping violation occurred." ${ }^{171}$ In such cases, the breach of procedural fairness will likely result in any sanction on the athlete being overturned.

\subsection{Issues with the cure the defect provision}

While the de novo review mechanism which is built into the CAS procedure allows panels to cure procedural defects, one should not disregard regularly occurring procedural unfairness which occur in the national doping control process. As David (2017) notes:

\footnotetext{
$\overline{165}$ WADA Code (2021), Article 13.1.1.

166 CAS Code of Sports-related Arbitration, Rule 57.

167 Charles Fernando Basilio da Silva v. FC Lokomotiv Moscow (CAS 2015/A/4187), award of 25 April 2016, para 101.

168 Ibid.

169 Amar Muralidharan v. Indian National Anti-Doping Agency (NADA), Indian National Dope Testing Laboratory, Ministry of Youth Affairs and Sports (CAS 2014/A/3639), award of 8 April 2015, para 89, citing B. v. Fédération Internationale de Natation (FINA) (CAS 98/211), award of 7 June 1999 (Pierre Moor, Droit Administratif, vol. II, Berne 1991, p. 19, citing Swiss Supreme Court cases ATF 114 Ia 307, ATF 110 Ia 81; see also Calvin v. Carr (1980) AC 574, pp. 592-593. See also, David 2017, p. 323, noting that there are numerous CAS awards where CAS has relied on a de novo re-hearing to cures defects in the earlier process, including for example, Danuite $v$. International DanceSport Federation (CAS 2006/A/1175), award of 26 June 2007, para 61.

170 See e.g., USA Shooting and Q. v. Union Internationale de Tir (UIT) (CAS 94/129), award of 23 May 1995, para 59.

171 Amar Muralidharan v. Indian National Anti-Doping Agency (NADA), Indian National Dope Testing Laboratory, Ministry of Youth Affairs and Sports (CAS 2014/A/3639), award of 8 April 2015, para 68.
} 
One of the key areas for work and development is in building up the standard and uniformity of firstinstance hearing processes. While WADA's appeal right is one way of correcting erroneous approaches, it will be far better overall if first-instance tribunals can be expected to apply the Code properly and produce the required decisions quickly. ${ }^{172}$

This point has been raised from the perspective of judicial review in common law jurisdictions, for example:

"The view that a fair appellate procedure can ... be a cure for an unfair trail does not tend to belittle the imperatives of a fair procedure at both stages. It may also be said that in a case where there is failure of natural justice in the original proceedings, the "appeal" ceases to be an appeal and reduces itself to a correct original hearing, and no appeals." 173

Even CAS panels have noted that it would be “... wise to ensure that accused competitors are given a satisfactory opportunity to be heard from the start, so that they do not feel impelled to appeal out of frustration..."174 Thus, it would be inadequate to suggest that all defects are cured on appeal.

Commentators have noted that "...on considerations of fairness, then, the jurisprudence of the CAS would appear to provide cause for concern". ${ }^{175}$ Noting further that "the CAS should be more hesitant to accept that the procedural error of a federation court has been cured by means of a hearing before the CAS. In such cases, the CAS should only accept that an error has been cured if it can rule out that the procedural error influenced the result of the federation's decision." 176

Typically, even when an athlete appeals a domestic decision to the CAS on procedural grounds, the appeal panel does not need to consider any procedural allegations in detail as these issues can be remedied via the appeal. ${ }^{177}$ This has been the case previously for allegations that the original panel was biased ${ }^{178}$; that the wrong burden of proof has

\footnotetext{
$\overline{172}$ David 2017, p. 546.

173 Sreeshyla Industries Employees' Union vs State Bank of India and Anr., 1984 (2) KarLJ 105, 47.

174 USA Shooting and Q. v. Union Internationale de Tir (UIT) (CAS 94/129), award of 23 May 1995, para 59.

175 Vieweg 2014, p. 389.

176 Vieweg 2014, p. 393, citing McLaren 2011, p. 54.

177 Lambert 2009, p. 429.

178 B. v. Fédération Internationale de Natation (FINA) (CAS 98/211), award of 7 June 1999, para 266, (the CAS panel did not find it necessary to consider whether the original panel had exhibited bias because the nature of de novo review made such considerations unnecessary); B. v. International Weightlifting Federation (IWF) (CAS 2004/A/607), award of 6 December 2004 (although the original
}

been applied by the panel ${ }^{179}$; that the athlete's right to a fair hearing and procedural fairness was violated by the panel ${ }^{180}$; and, that the right of cross-examination was not provided and that there was no distinction between the disciplinary body and the investigatory body. ${ }^{181}$ Not considering the alleged procedural flaws from first instance hearings (even as obiter dicta) is a missed opportunity for the CAS to set normative standards in interpreting the WADA Code and other applicable laws. A clear interpretation of the scope of these procedural norms would inform future domestic panels on the types of procedural conduct that they should be striving for (or conduct they should be avoiding) and ensuring that they are holding themselves accountable to these standards. The approach adopted by the ECHR in Ali Riza v. Turkey, where the Court thoroughly examined allegations of procedural unfairness at first instance and effectively ordered structural reforms, illustrates the potential impact that review by the ECHR (and indeed even the CAS) can have on remedying structural procedural defects. While national first instance hearing panels are not formally bound by CAS decisions, legal counsel and arbitrators from first instance panels around the world regularly refer to CAS jurisprudence when reaching their decisions. As such, making determinations on procedural guarantees will be particularly important in interpreting the new standards enshrined in the ISRM, for which there are some provisions with limited jurisprudence.

At a more practical level, the CAS can only "cure" defects of cases that are appealed to it. The vast majority of antidoping cases are not appealed to the CAS. That is, the de novo right of the CAS to review all doping cases in their entirety is in and of itself not sufficient to deal with the issue

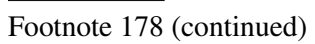

panel did not provide a fair hearing, the issue could be remedied at CAS because of the de novo review), cited in Lambert 2009, p. 429.

179 B. v. Fédération Internationale de Natation (FINA) (CAS 98/211), award of 7 June 1999, paras 9-10 (not considering allegations made by the athlete that the panel had incorrectly applied the burden of proof as this could be corrected on the de novo appeal), cited in Lambert 2009, p. 429.

${ }^{180}$ B. v. International Weightlifting Federation (IWF) (CAS 2004/A/607), award of 6 December 2004 (finding that the original panel had not respected all aspects of due process, but dismissing this issue because of the nature of de novo review); See N. v. Fédération Internationale de Natation Amateure (CAS 98/208), award of 22 December 1998 (finding it unnecessary to consider the athlete's allegation that the original panel violated the appellant's right of due process as the de novo review can remedy such defects), cited in Lambert 2009, p. 429.

181 USA Shooting and Q. v. Union Internationale de Tir (UIT) (CAS 94/129), award of 23 May 1995, paras 13-14, (CAS did not determine whether the original panel hearings violated the athlete's right to due process based on the allegations that the person bringing the case was also the person imposing the sanction, as such procedural injustices can be cured on appeal in any event). 
of systemic violations of procedural fairness. Indeed, relying on this de novo right in many respects deals with the symptoms of procedural flaws in the system rather than the cause of the problem. A brief look at statistics helps illustrate this point.

By way of illustration, in India only 14 athletes have had their anti-doping violation cases appealed to the CAS. This is a total of just over $1 \%$ of the 1038 cases where an athlete was found to have committed an anti-doping violation by India's Anti-Doping Disciplinary Panel, since its inception in 2009. ${ }^{182}$ Interestingly, out of these 14 cases, 13 were appealed by WADA or the relevant international sport federation and one ${ }^{183}$ was appealed by an athlete. In some respects, the fact that only one Indian athlete has ever appealed their case to the CAS may in itself be prima face evidence of access to justice issues in the anti-doping dispute resolution framework. Indeed, it is telling that only one out of 1038 athletes has had the opportunity to appeal their case to the CAS and have the matter heard de novo by the international appellate court. Importantly, the fact that approximately $1 \%$ of Indian doping disputes are heard by the CAS means that up to $99 \%$ of cases are going unchecked. Issues of delay, access to justice and other procedural irregularities may threaten to undermine fairness in the entire anti-doping process if they remain unchecked. While there is limited empirical evidence on the rates of appeal in anti-doping cases, the number of cases appealed to the CAS from domestic panel hearings appears to be lower than appellate rates in traditional courts. ${ }^{184}$ In any event, while further empirical research is required in this regard, one could hypothesize that under the current WADA framework, the majority of procedural defects are not being cured, as most cases are not being appealed to the CAS in the first place.

Other limitations of the de novo appeal system have also been argued by commentators, noting that the multiple tiers of review are potentially a waste of additional time and expense, claiming that " $[\mathrm{a}]$ de novo review prolongs and significantly increases the cost of the process by requiring both sides to repeat the full hearing conducted below and to again incur full costs.". ${ }^{185}$ While the introduction of single hearings before the CAS Anti-Doping Division may to some extent water down this argument, the questions of the

\footnotetext{
182 NADA 2020.

183 Amar Muralidharan v. Indian National Anti-Doping Agency (NADA), Indian National Dope Testing Laboratory, Ministry of Youth Affairs and Sports (CAS 2014/A/3639), award of 8 April 2015.

184 By contrast, see Eisenberg 2004, p. 659, noting that appeals from District Courts to the Federal Court in the United States "are filed in $10.9 \%$ of filed cases, and $21.0 \%$ of cases if one limits the sample to cases with a definitive judgment for plaintiff or defendant.".

185 Weston 2009, p. 127.
}

accessibility and affordability of the CAS still remain for many athletes.

Finally, empirical research shows that there is an underrepresentation of developing countries on the CAS panel of arbitrators. ${ }^{186}$ According to Lindholm's (2019) analysis of more than 2000 arbitrator appointments to CAS, "more than 77 percent went to arbitrators based in Europe, and arbitrators from Europe, Oceania, and North America collectively received 94 percent of all CAS appointment. By comparison, less than 4 percent of the appointments went to arbitrators based in Asia." ${ }^{187}$ It should be noted that Asia has almost six times the population of Europe. Consequently, national panels, especially in those parts of the world who are underrepresented in the CAS, may be better placed to understand the socio-economic contexts from where the athletes operate, ${ }^{188}$ thereby strengthening the argument of the importance of first instance hearings. While further discussion on the demographic representation of arbitrators is outside the scope of this paper, further research may be warranted to better understand the relatively small pool of arbitrators which are regularly appointed to hear CAS cases, despite a large and growing list of available CAS arbitrators from around the world.

\section{Procedural fairness in developing countries: a case study}

Some commentators argue that athletes from less developed countries are worse off under the current system. ${ }^{189}$ Efverström and Bäckström (2017) note that in the anti-doping framework "inequities and structural injustice emerge on an individual level because of the varying contexts and conditions." ${ }^{190}$ Some commentators argue that an attempt to harmonize such an approach "... assumes that the values set out by middle-class Western men in developed countries with a history of amateur sports ideologies can be transferred to the rest of the world." ${ }^{191}$ Aside from this theoretical debate, it is now well documented that there are fewer CAS arbitrators from Asian countries and other parts of the developing world. ${ }^{192}$

The dispute resolution procedures in developing countries are often criticized for their lengthy delays and access to

\footnotetext{
$\overline{186}$ Sethna 2019; Lindholm 2019, pp. 270-274.

187 Lindholm 2019, p. 271.

188 See, e.g., Dasgupta 2019, p. 122.

189 See e.g., Kayser et al. 2007, p. 3.

190 Efverström and Bäckström 2017, p. 8.

191 Dimeo and Møller 2018, p. 56.

192 Lindolm 2019; pp. 270-274; Sethna 2019.
} 
justice issues, and the doping control process is no different. ${ }^{193}$ One illustration of the procedural irregularities that may exist at the domestic level in developing countries is the Amar case. ${ }^{194}$ Importantly, the Amar case is the only Indian case to have been appealed to the CAS by an athlete. As one of 1038 anti-doping violations by Indian athletes, Amar represents the frustration of many Indian athletes with the procedural irregularities in the system. ${ }^{195}$

Amar, an Indian swimmer, tested positive to methylhexaneamine (MHA), a banned substance under the WADA Code, during an in-competition test at the Indian national championships in August 2010. The athlete was notified of the anti-doping rule violation in September 2010 (where he was provisionally suspended) but the case was subsequently heard for the first time by the Anti-Doping Disciplinary Panel (ADDP) 2 years later in September 2012. After further delays in the ADDP issuing its award, imposing a 2-year suspension on 5 November 2012, taking into account the time Amar had served under his provisional suspension. Thus, the entire sanction was served by the time ADDP reached its final determination. While this delay at first instance in itself illustrates procedural concerns, the athlete's appeal to the Anti-Doping Appellate Panel (ADAP) was heard on 13 March 2014, more than 13 months after the required deadline under the NADA Rules, ${ }^{196}$ and a decision was handed down by ADAP on 3 June 2014-almost 4 years after the alleged anti-doping violation. On appeal, the CAS held that, in doing so, the NADA had "undisputedly violated the Appellant's right to a procedure in line with the timing requirements". ${ }^{197}$ However, it was further held that the virtue of the CAS appeal system was its ability to cure any

\footnotetext{
${ }^{193}$ See cases involving Indian athletes, including World AntiDoping Agency v. Amit and National Anti-Doping Agency of India (CAS 2014/A/3869), award of 23 November 2015, para 63; World Anti-Doping Agency v. Nirupama Devi Laishram and National AntiDoping Agency of India (CAS 2012/A/2979), award of 8 November 2013, paras 119-120. See also, Venezuela: International Paralympic Committee (IPC) v. I., Venezuelan National Paralympic Committee (COPAVEN), Venezuelan National Anti-Doping Organization (VNADO) and Sport Federation for Visually Impaired Athletes in Venezuela (FEPOCIVE) (CAS 2012/A/2789), award of 17 December 2012; South Africa: WADA v. Gert Thys, Athletics South Africa and South African Institute for Drug-Free Sport (CAS 2011/A/2435), award of 30 November 2011.

194 World Anti-Doping Agency v. Amit and National Anti-Doping Agency of India (CAS 2014/A/3869), award of 23 November 2015.

195 See also, Rahul Mann v. National Anti-Doping Agency, Appeal No. 15.ADAP.12 (Anti-Doping Appeal Panel, India), award of 11 February 2014; Rajeev Tomar v. National Anti-Doping Agency, Appeal No. 18.ADAP.12 (Anti-Doping Appeal Panel, India), award of 11 February 2014

196 National Anti-Doping Rules, 2010 (India), Rule 8.3.8.

197 CAS 2014/A/3639, para 88.
}

procedural defects. ${ }^{198}$ The athlete's entitlement, it was held, "was to a system which allowed any defects in the hearing before the ADDP and ADAP to be cured by the hearing before the CAS". 199

The sole arbitrator acknowledged that:

Article 8.3 of the NADA ADR (which, in essence, follows Article 8.1 of the WADA Code) provides inter alia for detailed procedural rights of athletes as to being provided fair and timely information of the asserted anti-doping rule violation, an expedited hearing for a provisional suspension, and a fair hearing on whether the asserted anti-doping rule violation has been committed. ${ }^{200}$

It was further acknowledged that this provision had not been complied with in the initial proceedings against the athlete. However, given that the CAS has the power for $d e$ novo review, the sole arbitrator determined that the procedural delays that took place before ADDP and ADAP can be cured by a full CAS hearing. Since the delay did not "unduly prejudice his right to obtain evidence, interview witnesses, or adequately defend the claims brought against him". ${ }^{201}$ The Sole Arbitrator held that "while the NADA showed an alarming inability to effectively, timely, and appropriately handle the Appellant's case, such delay did not fundamentally violate the Appellant's procedural rights."202

This was the first recognition by the CAS that Indian dispute resolution bodies were allowing undue delay and violations of athletes' rights of procedural fairness. While a de novo review of this case may cure defects for this particular case, the dispute resolution process was in violation with the express time limits of the NADA Rules, 2010, and in clear violation of the procedural rights of the athletes, as acknowledged by the CAS.

These types of violations of procedural norms are inconsistent with the concept of fairness that the WADA Code purports to uphold. Many commentators would argue that unreasonable delays such as those in the Amar case undermine the athlete's right to a fair trial and are unjust. Yet, despite this, the CAS maintains that it can cure all such defects on appeal. That aside, relying only on the de novo mechanism of the CAS to fix procedural problems in the system is short sighted and focusses only on the case at hand.

The de novo right of review of the CAS may be an effective mechanism to fix some procedural defects but only when such cases are appealed to the CAS. Although the Amar

\footnotetext{
198 CAS 2014/A/3639, para 89.

199 CAS 2014/A/3639, para 89.

200 CAS 2014/A/3639, para 85.

201 CAS 2014/A/3639, para 91.

202 CAS 2014/A/3639, para 91.
} 
award was handed down by the CAS on 8 April 2015 (more than 4 years after his anti-doping violation), it remains the only case to have been appealed to the CAS by an Indian athlete. While no empirical research exists with respect to how many cases from developing countries are appealed to the CAS, the fact that only one of more than 1000 Indian athletes has appealed a decision to the CAS is significant. In addition, the CAS has repeatedly criticized the unreasonable delays of the first instance hearing procedures of some developing countries. ${ }^{203}$ As such, since only a small percentage of cases are heard by the CAS, it is axiomatic that most procedural defects will remain undiagnosed and uncured.

Further empirical research is required on procedural fairness in the anti-doping dispute resolution process across jurisdictions. Such research may provide robust data to support reform. ${ }^{204}$ Specifically, research should consider:

- The extent of compliance with procedural fairness norms as required under the applicable rules, and adherence to time limits under the ISRM and domestic rules, by domestic panels and NADOs in domestic anti-doping disputes, particularly from developing countries such as India;

- The nature and prevalence of access to justice issues existing at a domestic level and whether they are preventing athletes from appealing to the CAS;

- Comparative procedural fairness issues across developed and developing countries such as India;

- What athletes consider the barriers of appealing their disputes to the CAS to be and what mechanisms would remove or reduce these barriers from the perspective of athletes, including inter alia improving access to legal aid for quality legal counsel and scientific expertise, promoting regional CAS hearings, and reducing language barriers; and

- A detailed analysis of the current structure of the CAS to consider to what extent allegations of impartiality and independence have merit and whether structural

\footnotetext{
203 Venezuela: International Paralympic Committee (IPC) v. I., Venezuelan National Paralympic Committee (COPAVEN), Venezuelan National Anti-Doping Organization (VNADO) and Sport Federation for Visually Impaired Athletes in Venezuela (FEPOCIVE) (CAS 2012/A/2789), award of 17 December 2012; South Africa: WADA v. Gert Thys, Athletics South Africa and South African Institute for Drug-Free Sport (CAS 2011/A/2435), award of 30 November 2011; Simpson v. Jamaica Anti-Doping Commission, CAS 2014/A/3572 (2015); Powell v. Jamaica Anti-Doping Commission, CAS 2014/A/3571 (2015); World Anti-Doping Agency v. Amit and National Anti-Doping Agency of India (CAS 2014/A/3869), award of 23 November 2015.

204 See Viret 2020, p. 83, for a discussion on the fact that legal academics and practitioners should play a critical role in interdisciplinary research in anti-doping, ensuring ".. that the resulting insights are appropriately transposed into regulatory terms".
}

improvements are necessary to improve legitimacy of these institutions. ${ }^{205}$ Similar research is also warranted to determine perspectives of operational and institutional independence of first instance and appellate panels.

\section{Conclusion}

The applicable law, CAS jurisprudence, WADA Code and commentaries all uphold the virtues of procedural fairness in anti-doping disputes. This has been reinforced given the minimum mandatory standards set out in the ISRM and the 2021 WADA Code. Despite this, there are gaps in the application of procedural fairness rights of athletes, particularly at a domestic level. Given the positive reforms in some developed countries, as opposed to the access to justice issues and the systemic procedural issues that exist in some developing countries, the difficulties of compliance with procedural norms may be more prevalent in developing countries. The Indian system, and in particular, the Amar case illustrates this point.

An athlete's right to procedural fairness is a central tenet of the functioning of the anti-doping dispute resolution framework. The scope of this right includes ensuring that athletes have a (i) fair, impartial and independent hearing; (ii) an accessible and affordable hearing process, including providing the athlete with the opportunity for legal counsel, albeit at their own expense; and (iii) a process that ensures a timely resolution of any alleged violation. Issues of procedural fairness are particularly pertinent given the current Covid-19 crisis, where an athlete's right to a decision within a reasonable time is likely to be further delayed, especially where domestic panels do not permit or commonly allow hearings via teleconference. ${ }^{206}$ In addition, physical distancing constraints and lockdowns may further impact an athlete's ability to liaise with legal counsel or domestic panels, especially if access to technology is an issue. These concerns may disproportionally impact athletes from some developing countries, ${ }^{207}$ further widening the gap between procedural fairness standards. Despite the obvious practical difficulties of physical distancing and access to technology in some

\footnotetext{
205 See e.g., Mutu and Pechstein v. Switzerland, 40575/10 and 67474/10, 2 October 2018, Dissenting Opinion of Judges Keller and Serghides, para 2.

${ }^{206}$ In contrast, the applicable rules in some developed countries provide for hearings via teleconference and these procedural rules are regularly used by the domestic panels. See, for instance, Sports Tribunal of New Zealand, Rules of the Sports Tribunal of New Zealand 2012, r 37; David 2016, p. 139.

207 See, in contrast, "the Brazilian Dispute Resolution Chamber ... 100\% online from its inception, making an in-person hearing an exception rather than a rule..." (LawInSport 2020, para 47).
} 
countries, "the interests of justice are not served by delaying all hearings until they can be conducted in person". ${ }^{208}$

Given the severity of the consequences of a doping violation against an athlete, one would hope that the right to procedural fairness is observed in every case. However, a perusal of CAS jurisprudence shows that this is not always the case, as relying only on the CAS de novo review mechanism is not enough to ensure procedural fairness in all cases. As David (2017) notes, "[m]ost cases do not go to re-hearing before CAS on appeal. This system places a heavy emphasis on the standard of first-instance hearings." 209

Further empirical evidence of domestic anti-doping disputes is required to investigate the extent athletes' rights of procedural fairness are being upheld at all levels of the dispute resolution process, particularly in developing countries. This research may include a frequency analysis of the time taken between the alleged violation and final decision per anti-doping violation case, as well as an analysis of how many athletes are represented by legal counsel in anti-doping hearings at a domestic level. A comparative analysis would be valuable in this regard, given that some commentators have extolled the virtues of more developed dispute resolution institutions, such as anti-doping tribunals in New Zealand, in ensuring the "just, speedy and inexpensive" resolution of anti-doping disputes. ${ }^{210}$

In addition to further empirical research on procedural fairness in anti-doping, the CAS, WADA and NADOs can each play a critical role in setting and maintaining high standards in anti-doping procedures.

From the perspective of the CAS, when an athlete alleges procedural flaws at first instance, the panel ought to take the opportunity to set normative standards in interpreting the WADA Code and other applicable laws. During its de novo review, the CAS should consider legitimate procedural flaws at first instance and make an assessment of how and why they fall inside or outside the scope of procedural fairness standards. This would set a clear interpretation of the scope of these procedural norms and would inform future domestic panels on the types of procedural conduct that they should be striving for and ensuring that they are holding themselves accountable to these standards. ${ }^{211}$ Similarly, the SFT and

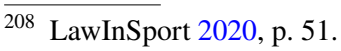

209 David 2017, p. 545.

${ }^{210}$ See, e.g., Sports Tribunal of New Zealand, Rules of the Sports Tribunal of New Zealand 2012, r 30. See also, David 2016, p. 134, 137, 142.

${ }^{211}$ For instance, an athlete may allege that a domestic appellate body lacked the institutional and operational independence to hear a dispute. The CAS will be in a position in such a case to further interpret the meaning and scope of independence of domestic tribunals and under what circumstances these tribunals would not meet the minimum guarantees under the ISRM and Article 8 of the WADA Code. Currently, the CAS typically argues that whether the first instance
}

ECHR may again in the future hear allegations of procedural unfairness, including lack of independence and impartiality of the CAS. Such circumstances would provide these Courts with the opportunity to give further consideration to the issue of independence of the CAS as this goes to the very legitimacy and credibility of the institution. Indeed, the ECHR in Ali Riza v. Turkey, illustrated the role that courts can play in properly examining allegations of procedural unfairness that have occurred at first instance and handing down judgments that promote upholding the importance of procedural fairness in sport. However, since the majority of anti-doping cases are not appealed to the CAS, the substantial burden or ensuring procedural fairness at first instance disputes ought to be on domestic panels, NADOs and WADA.

NADOs and other anti-doping signatories need to quickly adopt the revised rules and, most importantly, ensure that the minimum standards under the ISRM are adequately implemented. The fact that some NADOs have reformed dispute resolution infrastructure, conducted internal monitoring, and constantly sought to improve their procedures is significant. Such best practices should be followed by NADOs around the world. In its 2021 Model Rules for NADOs, WADA permits NADOs to delegate the first instance hearing process to an independent third party, such as Sports Resolutions or the CAS Anti-Doping Division. ${ }^{212}$ In doing so, WADA has effectively acknowledged that some first instance tribunals are more effective than others in achieving the goals of the WADA Code, including meeting the procedural standards. While some reforms and improvements may incur an expense, some cultural shifts and institutional changes require more of a concerted effort than a financial investment. NADOs should: (i) consider setting up pro bono panels and legal assistance for athletes without means which will reduce barriers of access to legal counsel; (ii) strictly adhere to time limits set by their own rules and now under the ISRM; and (iii) promptly take measures to ensure operational and institutional independence of domestic panel and appellate bodies. In addition, in some jurisdictions anti-doping rules set stricter procedural safeguards than prescribed by WADA, especially with respect to time limits (as discussed above). If domestic panels fail to meet the stricter procedural standards prescribed under the

\footnotetext{
Footnote 211 (continued)

panel or appellate body was independent and impartial is irrelevant because the CAS has the right of full review. The authors argue that this is a missed opportunity to clarify the scope of these important procedural guarantees under the WADA Code and provide clear boundaries for first instance and domestic appellate panels.

212 WADA specifically mentioned Sports Resolutions and the CAS Anti-Doping Division in the 2021 Model Rules for National AntiDoping Organizations, Note to 7.2 and Note to 8.1 .
} 
applicable anti-doping rules, it will be the responsibility of Government signatories of WADA and NADOs to monitor and ensure compliance. ${ }^{213}$

From WADA's perspective, while the reforms under the ISRM as to the outer limits of what constitutes a "reasonable time" is a significant step in the right direction, WADA still has important role to play in ensuring compliance. With its existing infrastructure, WADA should provide operational and technical support to allow NADOs to achieve and maintain full compliance with procedural fairness norms. The ISCCS prescribes that such support may include providing advice and information, by developing resources, guidelines, training materials, and training programs, and by facilitating partnerships with other NADOs where possible. ${ }^{214}$ Under the WADA Code, WADA should ensure that it appropriately monitors and enforces compliance of NADOs in accordance with the ISCCS. ${ }^{215}$ Under the ISCCS, the strict minimum procedural standards under the WADA Code and ISRM are identified as "critical requirements in the fight against doping in sport". ${ }^{216}$ Of particular relevance, the ISCCS notes all signatories must ensure:

"the proper and timely pursuit of all ... potential antidoping violations in accordance with ... the International Standard for Results Management, and provisions for a hearing within a reasonable time by a fair, impartial, and operationally independent hearing panel in accordance with Code Article 8.1". ${ }^{217}$

WADA should ensure that NADOs self-assess and selfreport on the procedural fairness requirements under the WADA Code and time limits and other procedural guarantees stipulated under the ISRM. ${ }^{218}$ WADA needs to hold NADOs and first instance panels accountable for lapses in procedural fairness and systemic delays. In the event of a non-compliance with the procedural guarantees, WADA can

\footnotetext{
213 Since the WADA Code and ISCCS are silent who bears the responsibility of enforcing compliance with these stricter measures prescribed under national anti-doping rules, it will be the responsibility of Government signatories of WADA and NADOs to monitor and ensure that domestic panels comply with such measures. In fact, the WADA Code (2021) acknowledges that “ $\ldots$ it is not necessary for effective harmonization to force all Signatories to use one single Results Management process as long as the process utilized satisfies the requirements stated in the Code and the International Standard for Results Management." (WADA Code (2021), Comment 5, p. 16). This reinforces that there is some flexibility in the drafting and enforcement of procedural rules, as long as they comply with the minimum standards prescribed by WADA.

214 WADA Code (2021), Article 20.7.3. See also, ISCCS, Article 6.2.

215 WADA Code (2021), Article 24.1.

216 ISCCS, Annex A, A.3.

217 ISCCS, Annex A, A.3 (k). (Italics omitted).

218 See ISCCS, Article 7.4.1.1.
}

allege a non-compliance by NADOs and request that it be rectified. As a "last resort", WADA can propose that CAS impose consequences should the NADOs not correct such systemic procedural problems. ${ }^{219}$

WADA should ensure compliance with the WADA Code-not only from the perspective of the substantive compliance by athletes-but also from the perspective of NADOs and international governing bodies in ensuring the procedural fairness of athletes are maintained in every case, as far as possible. Harmonization is desirable under the WADA Code. However, harmonization with respect to procedural fairness and the enforcement of the procedural guarantees under the WADA Code can only be achieved if WADA uses the infrastructure that it has put in place, by closely monitoring first instance procedures, and, if necessary, uses the compliance measures available to it under the ISCCS. It is critical that NADOs and national panels are held accountable to the strict procedural standards imposed under the WADA Code, just as athletes are held accountable to the strict standards imposed on them.

Acknowledgements The authors would like to acknowledge and thank Dr. Jack Anderson for his feedback and advice throughout the preparation of this paper.

Author's contributions SS (primary author and Ph.D. Candidate), SK (Ph.D. Supervisor).

Funding Not applicable.

Data availability Not applicable.

\section{Compliance with ethical standards}

Conflict of interest The authors declare that they have no conflict of interest.

Code availability Not applicable.

\footnotetext{
${ }_{219}$ See ISCCS, Article 5.4. See also WADA Code (2021), Article 24.1. The possible consequences that may be imposed on NADOs for violating the WADA Code and International Standards are set out in Article 24.1.12 of the WADA Code (2021).
} 


\section{Appendix A: Time limits prescribed under national anti-doping rules}

\begin{tabular}{ll}
\hline Country & Time limits \\
\hline Canada & Canadian Anti-Doping Programme (2015): \\
& The Doping Tribunal shall commence the hearing pro- \\
& cess no later than forty-five (45) days from the date \\
of the CCES' notification asserting an anti-doping \\
rule violation, except in matters involving Provi- \\
sional Suspensions, unless there is agreement on a \\
revised schedule between the Athlete or other Pers \\
the CCES asserts to have committed an anti-doping \\
rule violation and the CCES. (Article 8.2.1) \\
The Doping Tribunal shall issue an initial decision \\
no later than five (5) days from the completion of \\
the hearing. The Doping Tribunal shall also issue \\
a reasoned decision no later than twenty (20) days \\
from the completion of the hearing that includes \\
the full reasons for the decision and for any period \\
of Ineligibility imposed, including (if applicable) a \\
justification for why the greatest potential Conse- \\
quences were not imposed. (Article 8.3.1)
\end{tabular}

Ethiopia Ethiopian National Anti-Doping Office Rule (2017):

Hearings shall be scheduled and completed within a reasonable time. (Article 8.2.1)

Hearings for appeals shall be completed expeditiously and in all cases within 3 months of the date of the decision of the Doping Hearing Panel, save where exceptional circumstances apply. (Article 13.2.2.1.7).

Results Management Guiding Procedure (2017):

In the interest of fair, effective sport justice, any asserted ADRV should be prosecuted in a timely manner. Irrespective of the type of ADRV involved, ETH-NADO should be able to conclude Results Management and the hearing process within a maximum of 6 months of the date of commission or of discovery of the ADRV. (Article 3.1)

India National Anti-Doping Agency Rules (2010):

Unless otherwise agreed between the parties, the AntiDoping Disciplinary Panel shall:

(a.) Commence the hearing within fourteen (14) days of the notification date (Article 8.3.8.1)

(b.) Issue a written decision within twenty (20) days of the notification date (Article 8.3.8.2)

(c.) Issue written reasons for the decision within thirty (30) days of the notification date. (Article 8.3.8.3)

National Anti-Doping Agency Rules (2015):

The Athlete may submit their written submissions with all documents they are relying in support of his/ her case before the Anti-Doping Disciplinary Panel within 20 days from the date of receipt of the notice for the constitution of Panel. (Article 8.3.7)

The anti-doping disciplinary panel shall:

(a.) Commence the hearing within 45 days of the constitution of the Anti-Doping Disciplinary Panel

(b.) Issue a written decision with its reasoning within 90 days of the constitution of the Anti-Doping Disciplinary Panel. (Article 8.4)

Jamaica JADCO Anti-Doping Rules (2015):

Hearings shall be scheduled and completed within a reasonable time. (Article 8.3.7)

\begin{tabular}{ll}
\hline Country & Time limits \\
\hline Kenya & The Kenya Anti-Doping Regulations (2020):
\end{tabular}

Kenya The Kenya Anti-Doping Regulations (2020):

For any Person who is asserted to have committed an anti-doping rule violation, ADAK shall provide a fair hearing within a reasonable time by a fair, impartial and Operationally Independent hearing panel in compliance with the Code and the International Standard for Results Management. (Article 8)

New Zea- $\quad$ Sports Anti-Doping Rules (2020):

land Proceedings under the Rules must be completed in a timely manner, and should normally be completed within 3 months of the date of notification of the Anti-Doping Rule Violation Proceedings to the Sports Tribunal by DFSNZ. (Article 8.7.1)

Pakistan Pakistan Anti-Doping Rules (2008):

Hearings pursuant to this Article should be completed expeditiously and in all cases within three (3) months of the completion of the results management process described in Article 7 (Results Management), save where exceptional circumstances apply. (Article 8.1.15)

Unless otherwise agreed between the parties, the National Anti-Doping Disciplinary Panel shall; - Commence the hearing within fourteen (14) days of the notification date;

- Issue a written decision within twenty (20) days of the notification date; and

- Issue written reasons for the decision within thirty (30) days of the notification date. (Article 8.1.16)

South Africa Anti-Doping Rules (2019):

When SAIDS sends a notice to an Athlete or other Person alleging an anti-doping rule violation ... then the case shall be referred to the Independent Doping Hearing Panel for hearing and adjudication. ... the hearings shall take place within 90 days of SAIDS sending a notice to the Athlete or other Person alleging an antidoping rule violation. Under exceptional circumstances, this delay may be extended only once for up to 30 days. (Article 8.1.3)

The Independent Doping Hearing Panel may adjourn the hearing and set a date for the continuation of the hearing within 60 days. (Article 8.2.5)

Within 60 days of the end of the hearing the Chairperson of the Independent Doping Hearing Panel shall issue a written, dated and signed decision ... that includes the full reasons for the decision and for any period of Ineligibility imposed, including (if applicable) a justification for why the greatest potential Consequences were not imposed. (Article 8.3.1)

United King- National Anti-Doping Panel Rules (2019):

dom Subject to Article 6.5, the hearing should take place no later than forty (40) days after the NADP Secretariat receives the Request for Arbitration, save where fairness requires, or the parties otherwise agree. (Article 7.8.1)

... the Tribunal shall announce its decision to the parties in writing, dated and signed by at least the Tribunal chairman within fifteen (15) working days of the end of the hearing. (Article 11.1) 


\section{References}

Ansley CC (1995) International athletic dispute resolution: tarnishing the olympic dream. Ariz J Int Comp Law 12:277-302

Australian Sports Commission (2008) Submission to the commonwealth government's independent review of sport in Australia. https://www.clearinghouseforsport.gov.au/_data/assets/pdf_ file/0004/248647/review.pdf. Accessed 3 July 2020

Bedford N, Weeks G (2016) Doping in sport: what role for administrative law? In: Haas U, Healey D (eds) Doping in sport: an in-depth analysis of impact. Hart Publishing, Oxford, pp 147-168

Bersagel A (2012) Is there a stare decisis doctrine in the court of arbitration for sport-an analysis of published awards for antidoping disputes in track and field. Pepper Disput Resolut Law J 12:189-213

Bingham, The Rt. Hon. Lord (2006) The rule of law. In: The sixth sir David Williams lecture, Centre for Public Law, Faculty of Law, University of Cambridge, 16 November 2006. https://www.cpl. law.cam.ac.uk/sir-david-williams-lectures/rt-hon-lord-binghamcornhill-kg-rule-law. Accessed 16 May 2020

Blackshaw I (2009) The rules of natural justice: what are they and why are they important in sports disciplinary cases? Int Sports Law $\mathbf{J}$ $1-2: 134-135$

Blackshaw I (2018) Sport today: towards a Lex Sportiva. J Sports Law Policy Gov 1(1):1-11

Casini L (2011) The making of Lex Sportiva by the court of arbitration for sport. German Law J 12(5):1317-1340

Cernic J (2012) Fair trial guarantees before the court of arbitration for sport. Human Rights Int Legal Discourse 6(2):259-283

Cernic J (2014) Emerging fair trial guarantees before the court of arbitration for sport. In: Conference paper no. 9/2014, European society of international law 10th anniversary conference, Vienna, 4-6 September 2014

Connolly R (2006) Balancing the justices in anti-doping law: the need to ensure fair athletic competition through effective anti-doping programs vs the protection of rights of accused athletes. Va Sports Entertain Law J 5(2):161-233

Costa JP (2013) Legal opinion regarding the draft 3.0 revision of the world anti-doping code. https://www.wada-ama.org/en/what-wedo/legal/legal-opinions-and-articles-on-the-code. Accessed 29 June 2020

Costa JP (2019) Legal opinion on the world-anti doping code, 26 September 2019. www.wada-ama.org/sites/default/files/resources/ files/avis_2019_code_mondial_en.pdf. Accessed 29 June 2020

Dasgupta L (2019) The world anti-doping code: fit for purpose? Routledge, London

David P (2013) A guide to the world anti-doping code: the fight for the spirit of sport, 2nd edn. Cambridge University Press, Cambridge

David P (2016) Hearing anti-doping cases in New Zealand. In: Haas U, Healey D (eds) Doping in sport: an in-depth analysis of impact. Hart Publishing, Oxford, pp 127-146

David P (2017) A guide to the world anti-doping code: the fight for the spirit of sport, 3rd edn. Cambridge University Press, Cambridge

Dimeo P, Møller V (2018) The anti-doping crisis in sport: causes, consequences, solutions. Routledge, New York

Duval A (2019) Time to go public? the need for transparency at the court of arbitration for sport. Yearbook of International Sports Arbitration. https://doi.org/10.1007/15757_2019_29

ECHR (2019) Guide on Article 6 of the European Convention on Human Rights: Right to a fair trial (Updated to 31 August 2019)

Efverström A, Bäckström Å (2017) Different societies-different conditions: lessons from anti-doping in elite sport on a global level. In: International network for doping research, conference on doping in sport, doping in society: lessons, themes, and connections.
https://ph.au.dk/fileadmin/user_upload/INDR_2017_Book_of_ Abstracts.pdf. Accessed 16 May 2020

Eisenberg T (2004) Appeal rates and outcomes in tried and nontried cases: further exploration of anti-plaintiff appellate outcomes. J Empir Legal Stud 1(3):659-688

Fortese F, Hemmi L (2015) Procedural fairness and efficiency in international arbitration. Gron J Int Law 3(1):110-124

Foster K (2006) Lex Sportiva and Lex Ludica: the court of arbitration for sports jurisprudence. Entertain Sports Law J 3(2):1-15

Galligan D (1996) Due process and fair procedures: a study of administrative procedures. Oxford University Press, Oxford

Greene PJ (2017) When athletes are wrongly sanctioned under the World Anti-Doping Code. Md J Int Law 32(1):338-345

Haas U (2016) Revising the world anti-doping code. In: Haas U, Healey D (eds) Doping in sport and the law. Hart Publishing, Oxford, pp 19-40

Hanstad DV, Skille EA, Loland S (2010) Harmonization of anti-doping work: myth or reality? Sport Soc 13(3):418-430. https://doi. org/10.1080/17430431003588036

Hard M (2010) Caught in the net: athletes' rights and the world antidoping agency. South Calif Interdiscip Law J 19:533-564

Hayes PJ (2007) The rule of law and sporting justice. Aust N Z Sports Law J 2(1):1-14

Head M (2017) Administrative law: context and critique, 4th edn. The Federation Press, Annandale

Hiltzik MA (2006) Athletes see doping case appeals as futile exercise. 11 December 2006, Los Angeles Times. http://articles.latim es.com/print/2006/dec/11/local/la-me-doping11dec11. Accessed 16 May 2020

Jacobs HL, Brandon LS (2018) The uniform plan: a cost-benefit analysis of a proposed CAS first-instance tribunal to hear all antidoping cases. Int Sports Law J 17:205-213

Johnson G (1985) Natural justice and legitimate expectation in Australia. Fed Law Rev 15:39-75

Kayser B, Mauron A, Miah A (2007) Current anti-doping policy: a critical appraisal. BMC Med Ethics 8(2):1-10. https://doi. org/10.1186/1472-6939-8-2

Lambert M (2009) The competing justices of clean sport: strengthening the integrity of international athletics while affording a fair process for the individual athlete under the world anti-doping program. Temple Int Comp Law J 23(2):409-441

LawInSport (2020) The impact of COVID-19 on procedures in sport disputes resolution: first report dated 12 June 2020. https://www. lawinsport.com/topics/covid19-impact/item/the-impact-of-covid -19-on-procedures-in-sport-disputes-resolution-first-report-12june-2020. Accessed 5 July 2020

Lindholm J (2019) The court of arbitration for sport and its jurisprudence: an empirical inquiry into Lex Sportiva. TMC Asser Press, The Hague

Lodge J (2008) Elite athletes in the 21st century: athlete rights and the law. In: Hickie TV, Hughes AT, Healey D, Scutt JA (eds) Essays in sport and the law. Australian Society for Sports History, Melbourne, pp 243-256

Mavromati D (2018) Applicability of swiss law in doping cases before the CAS and the swiss federal tribunal. In: Duval A, Rigozzi A (eds) Yearbook of international sports arbitration 2016. TMC Asser Press, The Hague, pp 17-39

McCutcheon P (1999) sports discipline, natural justice and strict liability. Anglo-Am Law Rev 28:37-72

McLaren R (2011) The court of arbitration for sport. In: Nafziger JAR, Ross SF (eds) Handbook on international sport law. Edward Elgar, Northampton, pp 32-64

NADA (2020) List of sportspersons tested positive against dope substances and sanction imposed by anti-doping disciplinary panel $\mathrm{w}$. e. f. 01-01-2009 till date. https://www.nadaindia.org/upload_file/ document/1584092086.pdf. Accessed 2 July 2020 
Nafziger JAR (2011) Defining the scope and structure of international sports law: four conceptual issues. Int Sports Law J 3-4:14-20

Nafziger JAR (2012) The principle of fairness in the Lex Sportiva of CAS awards and beyond. In: Siekmann RCR, Soek J (eds) Lex Sportiva: what is sports law? TMC Asser Press, The Hague, pp 251-272

Polvino AT (1994) Arbitration as a preventative medicine for olympic ailments: the international olympic committee's court of arbitration for sport and the future for the settlement of international sporting disputes. Emory Int Law Rev 8:347-381

Pound RW, Clarke K (2011) Doping in sport. In: Nafziger JAR, Ross DF (eds) Handbook on international sport law. Edward Elgar, Northampton, pp 133-161

Sethna R (2019) A data analysis of the arbitrators, cases and sports at the court of arbitration for sport. LawInSport. www.lawinsport .com/topics/sports/esports/item/a-data-analysis-of-the-arbitrator s-sports-and-cases-at-the-court-of-arbitration-for-sport?categ ory_id=672. Accessed 16 May 2020

Siekmann RCR (2011) What is sports law-Lex Sportiva and Lex Ludica-a reassessment of content and terminology. Int Sports Law J 3-4:3-13

Soek JW (2003) The WADA world anti-doping: the road to harmonisation. Int Sports Law J 2:2-10

Soek JW (2006) The strict liability principle and the human rights of the athlete in doping cases. TMC Asser Press, The Hague

Spigelman JJ (2000) Just, quick and cheap: a standard for civil justice. Aust Construct Law News1 70:5

Straubel M (2005) Enhancing the performance of the doping court: how the court of arbitration for sport can do its job better. Loyola Univ Chicago Law J 36(4):1203-1272

United Nations Human Rights Council (2020) Intersection of race and gender discrimination in sport. Report of the United Nations High Commissioner for Human Rights (Human Rights Council, Fortyfourth Session, 15 June-3 July 2020)
Vieweg K (2014) Lex Sportiva and the fairness principle. Int Sports Law Rev Pandekt 10(3-4):382-394

Viret M (2020) Using interdisciplinary tools to improve anti-doping: utopia or necessity? Int Sports Law J 20:82-113

WADA (2019) 2021 World anti-doping code and international standard framework development and implementation guide for stakeholders. https://www.wada-ama.org/en/resources/the-code/2021-world -anti-doping-code-and-international-standard-framework-devel opment-and

Weston MA (2009) Doping control, mandatory arbitration, and process dangers for accused athletes in international sports. Pepper Dispute Resolut Law J 10(1):5-50

Wood J, Howman D, Murrihy R (2018) Report of the review of Australia's sports integrity arrangements. Department of Health, Common Wealth of Australia, Canberra

Zuckerman AAS (1999) Justice in crisis: comparative dimensions of civil procedure. In: Zuckerman AAS, Chiarloni S, Gottwald P (eds) Civil justice in crisis: comparative perspectives of civil procedure. Oxford University Press, Oxford, pp 3-52

Zuckerman AAS (2006) Zuckerman on civil procedure: principles of practice, 2nd edn. Sweet and Maxwell, London

Zuckerman AAS (2009) Litigation management under the CPR: a poorly-used management infrastructure. In: Dwyer D (ed) The civil procedure rules ten years on. Oxford University Press, Oxford, pp 89-108

Publisher's Note Springer Nature remains neutral with regard to jurisdictional claims in published maps and institutional affiliations. 